\title{
Controls on boron incorporation in cultured tests of the planktic foraminifer Orbulina universa
}

\author{
Katherine A. Allen ${ }^{\text {a,* }}$, Bärbel Hönisch ${ }^{a}$, Stephen M. Eggins ${ }^{b}$, Jimin Yu ${ }^{a}$, Howard J. Spero ${ }^{c}$, Henry Elderfield ${ }^{\mathrm{d}}$ \\ a Lamont-Doherty Earth Observatory of Columbia University, 61 Route 9W, Palisades, NY 10964, USA \\ ${ }^{b}$ Research School of Earth Sciences, The Australian National University, Canberra ACT, Australia \\ c Department of Geology, University of California, Davis, CA 95616, USA \\ d Department of Earth Sciences, University of Cambridge, Downing Street, Cambridge, CB2 3EQ UK
}

\section{A R T I C L E I N F O}

\section{Article history:}

Received 22 December 2010

Received in revised form 12 June 2011

Accepted 9 July 2011

Available online 10 August 2011

Editor: G. Henderson

\section{Keywords:}

boron

seawater carbonate system

pH proxy

Orbulina universa

planktic foraminifera

\begin{abstract}
A B S T R A C T
Culture experiments with living planktic foraminifers reveal that the ratio of boron to calcium (B/Ca) in Orbulina universa increases from 56 to $92 \mu \mathrm{mol} \mathrm{mol}{ }^{-1}$ when $\mathrm{pH}$ is raised from $7.61+/-0.02$ to $8.67+/-0.03$ (total scale). Across this $\mathrm{pH}$ range, the abundances of carbonate, bicarbonate, and borate ions also change $\left(+530,-500\right.$, and $+170 \mu \mathrm{mol} \mathrm{kg}{ }^{-1}$, respectively). Thus specific carbonate system control(s) on $\mathrm{B} / \mathrm{Ca}$ remain unclear, complicating interpretation of paleorecords. B/Ca in cultured 0 . universa also increases with salinity (55-72 $\mu \mathrm{mol} \mathrm{mol}^{-1}$ from 29.9-35.4\%) and seawater boron concentration $\left(62-899 \mu \mathrm{mol} \mathrm{mol}^{-1} \mathrm{from}\right.$ 4-40 ppm B), suggesting that these parameters may need to be taken into account for paleorecords spanning large salinity changes $(\sim 2 \%)$ and for samples grown in seawater whose boron concentration ([B $\left.]_{S W}\right)$ differs from modern by more than $0.25 \mathrm{ppm}$. While our results are consistent with the predominant incorporation of the charged borate species $\mathrm{B}(\mathrm{OH})_{4}$-into foraminiferal calcite, the behavior of the partition coefficient $\mathrm{K}_{D}$ (defined as $[\mathrm{B} / \mathrm{Ca}]_{\text {calcite }} /\left[\mathrm{B}(\mathrm{OH})_{4}-/ \mathrm{HCO}_{3}-\right]_{\text {seawater }}$ ) cannot be explained by borate incorporation alone, and suggests the involvement of other $\mathrm{pH}$-sensitive ions such as $\mathrm{CO}_{3}^{2-}$ For a given increase in seawater $\mathrm{B}(\mathrm{OH})_{4}-$, the corresponding increase in $\mathrm{B} / \mathrm{Ca}$ is stronger when $\mathrm{B}(\mathrm{OH})_{4}-$ is raised by increasing $[\mathrm{B}]_{S W}$ than when it is raised by increasing $\mathrm{pH}$. These results suggest that $\mathrm{B}$ incorporation controls should be reconsidered. Additional insight is gained from laser-ablation ICP-MS profiles, which reveal variable B/Ca distributions within individual shells.
\end{abstract}

(c) 2011 Elsevier B.V. All rights reserved.

\section{Introduction}

The ocean exerts a strong influence on atmospheric $\mathrm{CO}_{2}$ levels and the short-term carbon cycle, and plays a key role in regulating the Earth's climate. For these reasons, it is important to constrain past variations in seawater carbonate chemistry and saturation state. Insight into this system has already been gained through analysis of marine sediment records whose properties are sensitive to changes in ocean chemistry. Further development of such proxies will better enable us to constrain past conditions and establish records against which models can be tested. In ocean regions where the marine carbonate system is closely linked to the atmosphere via gas exchange, quantifying changes in the surface ocean's carbonate system (including variables such as $\mathrm{pH}$, alkalinity, and $\left[\mathrm{CO}_{3}^{2-}\right]$ ) would enable researchers to reconstruct paleo- $\mathrm{pCO}_{2}$ levels and, in places of upwelling or downwelling, may shed light on past oceanatmosphere carbon exchange.

\footnotetext{
* Corresponding author. Tel.: +1 845365 8668; fax: +1 8453592931.

E-mail address: katallen@ldeo.columbia.edu (K.A. Allen).
}

Fully constraining the carbonate system requires knowledge of temperature, salinity, pressure, and two of the following six parameters: $\mathrm{pH},\left[\mathrm{CO}_{2}+\mathrm{H}_{2} \mathrm{CO}_{3}\right],\left[\mathrm{HCO}_{3}^{-}\right],\left[\mathrm{CO}_{3}^{2-}\right]$, total alkalinity (TA), and total dissolved inorganic carbon (DIC). Proxies for some of these parameters have been developed, but their associated secondary effects and calibration uncertainties (e.g. Katz et al., 2010) make it desirable to develop additional tools which can verify or complement these paleoestimates.

The theory behind $\mathrm{pH}$-dependent boron incorporation into the shells of foraminifera is rooted in the observed behavior of boron isotopes in seawater and carbonates. In seawater, the abundance and boron isotope composition $\left(\delta^{11} \mathrm{~B}\right)$ of borate $\left(\mathrm{B}(\mathrm{OH})_{4}^{-}\right)$both increase with $\mathrm{pH}$ (Hemming and Hanson, 1992). If borate is then incorporated during calcification of marine carbonates, the boron concentration and $\delta^{11} \mathrm{~B}$ of carbonates should be sensitive to seawater $\mathrm{pH}$. An incorporation equation was proposed by Hemming and Hanson, (1992):

$\mathrm{CaCO}_{3}+\mathrm{B}(\mathrm{OH})_{4}^{-} \rightleftharpoons \mathrm{CaHBO}_{3}+\mathrm{HCO}_{3}^{-}+\mathrm{H}_{2} \mathrm{O}$ 
$\mathrm{K}_{e q}=\frac{a_{\mathrm{CaHBO}_{3}} \cdot a_{\mathrm{HCO}_{3}^{-}} \cdot a_{\mathrm{H}_{2} \mathrm{O}}}{a_{\mathrm{CaCO}_{3}} \cdot a_{\mathrm{B}(\mathrm{OH})_{4}^{-}}}$

where $\mathrm{K}_{e q}$ describes the phases of Eq. 1 at equilibrium, and is constant for a given temperature, pressure, and seawater composition. Yu et al. (2007) then related this incorporation model to a property measurable by mass spectrometry: the ratio of boron to calcium in calcite $(\mathrm{B} / \mathrm{Ca})$. Assuming that in calcite, $\mathrm{Ca}^{2+} \approx \mathrm{CO}_{3}^{2-}$ and $\mathrm{CaHBO}_{3} / \mathrm{CaCO}_{3} \approx \mathrm{B} / \mathrm{Ca}$, and that $\mathrm{B}(\mathrm{OH})_{4}^{-}$and $\mathrm{HCO}_{3}^{-}$are the species relevant for calcification, gives:

$\mathrm{K}_{D} \approx \frac{[\mathrm{B} / \mathrm{Ca}]_{\text {calcite }}}{\left[\mathrm{B}(\mathrm{OH})_{4}^{-} / \mathrm{HCO}_{3}^{-}\right]_{\text {seawater }}}$

where $K_{D}$ is an apparent partition coefficient describing incorporation of boron into calcite relative to seawater composition. The exact chemical species and mechanisms involved, however, remain uncertain.

Although some B/Ca data are consistent with the current model's expectations, direct measurements on solid-phase coordination are controversial (Klochko et al., 2009; Sen et al., 1994). In solution, the borate ion is tetrahedrally-coordinated, while boric acid is trigonallycoordinated. Different interpretations of nuclear magnetic resonance (NMR) analyses on marine carbonates have recently sparked debate on which of these aqueous species is incorporated into calcite: only $\left[\mathrm{B}(\mathrm{OH})_{4}^{-}\right]$(Sen et al., 1994), or a mixture of $\left[\mathrm{B}(\mathrm{OH})_{4}^{-}\right]$and $\left[\mathrm{B}(\mathrm{OH})_{3}\right]$ (Klochko et al., 2009). The presence of trigonally-coordinated B in calcite led Klochko et al. (2009) to suggest that boric acid may be incorporated during calcification. However, NMR cannot definitively resolve this question because aqueous species coordination could change during adsorption and crystal formation (Sen et al., 1994; Tossell, 2006). It is possible that some tetrahedrally-coordinated borate is adsorbed, and then transformed to trigonal coordination in the solid. The presence of trigonal $\mathrm{B}$ in the lattice thus does not necessarily prove aqueous $\mathrm{B}(\mathrm{OH})_{3}$ incorporation, and the issue remains open. The resolution of this debate is important to interpretations of boron data from fossils because an uncertain mixture of boric acid and borate in shell calcite would severely complicate the relationship of $\mathrm{B} / \mathrm{Ca}$ to past carbonate system conditions. One of the main goals of our study is to re-evaluate the incorporation equation (Eq. 1) and partition coefficient (Eq. 3) using tight constraints from laboratory experiments with living foraminifera.

Empirical calibrations are necessary because foraminiferal calcite does not form in complete chemical equilibrium with seawater. Evidence of disequilibrium includes large B/Ca differences between species (Foster, 2008; Yu et al., 2007), covariance of oxygen and carbon isotopes in foraminiferal shells (Bijma et al., 1999; Ni et al., 2007; Spero et al., 1997), and biological mediation of calcification (Bentov et al., 2009; de Nooijer et al., 2008; Lea, 2003; Zeebe and Sanyal, 2002). These organisms grow within a seawater microenvironment (diffusive boundary layer, $\sim 500 \mu \mathrm{m}$ ) whose chemistry is influenced by respiration, calcification, and by photosynthesis of symbionts, if present (Jørgensen et al., 1985; Rink et al., 1998; Wolf-Gladrow et al., 1999), which can lead to offsets from bulk seawater chemistry. The kinetics of the system (including diffusion and hydration/dehydration of ions) may also play a role in $\mathrm{B}$ incorporation, though the experimentally indistinguishable diffusion coefficients of $\mathrm{B}(\mathrm{OH})_{4}^{-}$and $\mathrm{B}(\mathrm{OH})_{3}$ in seawater (Mackin, 1986) indicate that relative transport of these two ions in solution does not likely influence B incorporation. Finally, the presence of organic membranes and compounds can also influence the growth rate and composition of carbonates (e.g. Zuddas et al. (2003); Langer, (1992); Stumm and Morgan, (1996)), and may exert some control over calcite structure and element composition. Due to these considerations, we cannot predict the partitioning of B from pure theory. To increase proxy robustness, we must instead isolate and identify the environmental control(s) and thoroughly test any possible interfering effects.
Some empirical relationships between solution and solid B chemistry have already been established for marine carbonates. The relationship between $\delta^{11} \mathrm{~B}$ of surface-dwelling foraminifers with $\mathrm{pH}$ has been calibrated in laboratory experiments (Hönisch et al., 2003; Hönisch and Hemming, 2004; Sanyal et al., 1996), and downcore records have also revealed tight co-variation of $\delta^{11} \mathrm{~B}$ with ice core $\mathrm{CO}_{2}$ (Foster, 2008; Hönisch et al., 2009; Hönisch and Hemming, 2005; Sanyal et al., 1995). Similarly, B/Ca of synthetic calcites (Hobbs and Reardon, 1999) and the concentration of boron in calcite ([B] calcite of another species of cultured foraminifera, Globigerinoides sacculifer, both increase with $\mathrm{pH}$ (Sanyal et al., 1996). Studies of planktic foraminifera shells from sediment coretops have suggested that $K_{D}$ can be used to determine $\mathrm{pH}$ (once temperature is taken into account, $\mathrm{Yu}$ et al. (2007)) and/or [ $\mathrm{CO}_{3}^{2-}$ ] (Foster, 2008; Hendry et al., 2009), but the relative influences remain elusive. If the primary control were $\mathrm{pH}$, then $\mathrm{B} / \mathrm{Ca}$ could serve as a valuable companion proxy for $\delta^{11} \mathrm{~B}$, increasing confidence in paleo-pH reconstructions. If $\mathrm{B} / \mathrm{Ca}$ instead reflects $\left[\mathrm{CO}_{3}^{2-}\right]$, then it could theoretically serve as the second parameter needed for carbonate system calculations, although the close covariation of $\mathrm{pH}$ and $\mathrm{CO}_{3}^{2-}$ in seawater leads to large propagated uncertainties when predicting other carbonate system parameters (Rae et al., 2011; Yu et al., 2010).

The influences of non-carbonate-system variables on B/Ca are uncertain as well. Some planktic foraminifera species from pelagic sediments exhibit a positive relationship between $K_{D}$ and temperature in Globorotalia inflata, Globigerina bulloides (coretop samples), and Globigerinoides ruber (downcore) (Tripati et al., 2009; Yu et al., 2007). Alternatively, Foster, (2008) observed a negative $K_{D}$-temperature relationship for G. sacculifer, G. ruber, and Neogloboquadrina dutertrei (coretop). Inconsistent $\mathrm{K}_{D}-\mathrm{T}$ relationships from field data suggest that these pelagic samples are influenced by multiple seawater variables, that individual species are influenced by different mechanisms, and/or that the controlling factors have not yet been adequately identified.

Because salinity, temperature, and pH often covary in the modern surface ocean, it can be difficult to discern their separate influences on shell composition solely from sediment-trap and core-top samples. Another method to evaluate the physical controls on B incorporation is through elemental analysis of calcite precipitated by foraminifers from experimental solutions for which physical and chemical properties are well-constrained and can be varied independently. Here, we present calibration results from living planktic foraminifers grown in controlled laboratory experiments. The symbiont-bearing, subtropical-temperate species Orbulina universa was grown under a wide range of $\mathrm{pH}$, temperature, salinity, and boron concentration $\left([\mathrm{B}]_{S W}\right)$. We observe higher $\mathrm{B} / \mathrm{Ca}$ of foraminiferal calcite grown in solutions with higher $\left[\mathrm{B}(\mathrm{OH})_{4}^{-}\right]$, which is consistent with (but does not yet prove) a predominant incorporation of $\mathrm{B}(\mathrm{OH})_{4}^{-}$. Our data also indicate a small salinity and negligible temperature effect on $\mathrm{B} / \mathrm{Ca}$.

\section{Methods}

\subsection{Culturing procedures}

Culturing experiments were performed at the Wrigley Marine Science Center on Santa Catalina Island ( $\left.33^{\circ} 26^{\prime} 40^{\prime \prime} \mathrm{N}, 118^{\circ} 28^{\prime} 55^{\prime \prime} \mathrm{W}\right)$, during July and August 2008. Juvenile foraminifers were individually collected by scuba divers approximately $2 \mathrm{~km}$ NNE of Big Fishermans Cove, at a water depth of 2-8 m. Average surface water temperature and salinity during the study period were $21.1^{\circ} \mathrm{C}\left(19.5-22.0^{\circ} \mathrm{C}\right)$ and 33.0 (32.5-33.4 on the Practical Salinity Scale PSS-78, quoted hereafter as “\%”), respectively. Immediately after collection, samples were brought to the laboratory where the foraminifers were identified and maximum shell diameter was determined using light microscopes. If foraminifers did not already have food caught in their spines, they were fed a one-day old brine shrimp nauplius (Artemia salina) 
and then transferred to the experimental seawater. All specimens were subsequently fed an Artemia nauplius every 3 days.

All seawater used in experiments was collected offshore during collection dives, and then filtered through $0.8 \mu \mathrm{m}$ filters. Each experiment was designed to shift either the carbonate system, temperature, salinity, or $[\mathrm{B}]_{S W}$. In each experiment, 15 to 20 juvenile (pre-sphere) individuals were incubated in separate $125 \mathrm{ml}$ borosilicate glass jars. The large volume of culture water per organism ensured that the carbonate system of experimental seawater was not significantly affected by symbiont photosynthesis or respiration (Spero and Parker, 1985). Over the course of 3 to 14 days these foraminifers grew a spherical chamber typical for 0 . universa. Experiments ended after specimens underwent gametogenesis, at which point the spherical chamber was devoid of cytoplasm (Bé and Anderson, 1976; Hamilton et al., 2008).

We varied the $\mathrm{pH}$ of $4 \mathrm{~L}$ batches of filtered seawater by titrating drop-wise with $\mathrm{NaOH}$ or $\mathrm{HCl}$ (7.6-8.6, total scale). Salinity was modified between 29.9 and $35.4 \pm 0.1$ by diluting seawater with deionized water or by partial evaporation under a heat lamp at $60^{\circ} \mathrm{C}$. Boron concentrations were increased to approximately $5 \times$ and $10 \times$ the natural concentration by adding $404 \mathrm{mg}$ and $908 \mathrm{mg}$ of boric acid to $4 \mathrm{~L}$ seawater, followed by titration with $\mathrm{NaOH}$ to reestablish an ambient $\mathrm{pH}$ of 8.0 (total $\mathrm{pH}$ scale). Culture jars were placed in separate temperature-controlled water baths so specimens could be grown between $17.7 \pm 0.5$ and $26.5 \pm 0.2^{\circ}$. Temperature uncertainty represents the standard deviation of measurements made by in-tank sensors every 5 min for the duration of each experiment.

To minimize gas-exchange with the atmosphere, jars were completely filled with experimental seawater to eliminate gas headspace and sealed with parafilm and tight-fitting lids. To monitor potential atmospheric $\mathrm{CO}_{2}$ exchange during feeding (when caps must be removed), alkalinity and $\mathrm{pH}$ were measured at the beginning $(\sim 2$ water samples) and end of each experiment ( $\sim$ water samples). Alkalinity was measured using a Metrohm open cell auto-titrator, calibrated against Dickson-certified alkalinity standards. For all experiments, the initial-final alkalinity difference was $<1 \%$. The average initial-final $\mathrm{pH}$ change for all experiments was 0.02 , with a maximum of $0.06 \mathrm{pH}$ units for the high $\mathrm{pH}$ seawater, suggesting invasion of a small amount of $\mathrm{CO}_{2}$ during feeding for that experiment.

Carbonate system parameters were calculated using Mehrbach constants for the dissociation of carbonic acid and bicarbonate, $K_{1}$ and $\mathrm{K}_{2}$, refit by (Lueker et al., 2000) on the total pH scale. The Matlab program csys3.m (Zeebe and Wolf-Gladrow, 2004) was modified to allow full specification of seawater variables relevant to our experiments, including initial boron concentrations that deviate from the natural boron-to-salinity ratio. For each experiment, temperature, alkalinity and $\mathrm{pH}$ were measured several times as described above; averages were used to calculate the values presented in Table 1. To determine the upper (and lower) influence bounds of each measured seawater variable ( $\mathrm{T}, \mathrm{S}$, alkalinity, and $\mathrm{pH}$ ) on calculated carbonate system parameters, standard deviations were added to (and subtracted from) average values and used to fully recalculate the carbonate system. Each seawater variable's corresponding parameter ranges were then root-mean-square combined, and reported in Table $1( \pm \sigma)$.

Light levels were held at $406 \pm 108 \mu \mathrm{mol}$ photons $\mathrm{m}^{-2} \mathrm{~s}^{-1}$ by overhead fluorescent lamps (cool white, high output), monitored biweekly using a light meter. These light levels exceed the saturation intensity for the symbiotic dinoflagellate Gymnodinium béii associated with 0 . universa ( $386 \mu \mathrm{mol}$ photons $\mathrm{m}^{-2} \mathrm{~s}^{-1}$, Spero and Parker, (1985)) but falls well below photoinhibition, which has not been observed below $700 \mu \mathrm{mol}$ photons $\mathrm{m}^{-2} \mathrm{~s}^{-1}$ (Rink et al., 1998). All experiments were maintained on 12:12 h light:dark cycles. Every day, foraminifers were observed using $10 \times$ hand-lenses. Spine and symbiont presence, degree of chamber-fill, and sphere formation were recorded until each experiment was completed.

Experiments ended after foraminifers had undergone gametogenesis (dropped spines and released gametes). Approximately $90 \%$ of all individuals reached gametogenesis, and only these gametogenic foraminifers were archived for later analysis. Empty shells were rinsed in deionized water, dried, weighed and measured to determine growth during the experimental period.

\subsection{Elemental analysis}

Shells were crushed and cleaned following the methods of Russell et al. (2004). Previous laser ablation and bulk shell chemical analyses indicate that $\sim 15-20$ shells are needed to get a reliable average, so we combined at least 15 specimens from an experiment for each sample. Samples were rinsed with ultrapure (QD) water to remove fine particles, and then oxidized twice for $30 \mathrm{~min}$ with hot $\left(70^{\circ} \mathrm{C}\right)$, buffered $\mathrm{H}_{2} \mathrm{O}_{2}\left(0.1 \mathrm{~N} \mathrm{NaOH}, 15 \% \mathrm{v} / \mathrm{v} \mathrm{H}_{2} \mathrm{O}_{2}\right.$ Seastar) to remove organic matter. Following oxidation, samples were rinsed 5 times with ultrapure water and leached 3 times with $0.001 \mathrm{~N} \mathrm{HNO}_{3}$ to remove

Table 1

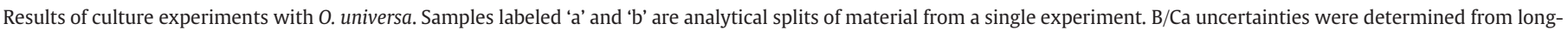

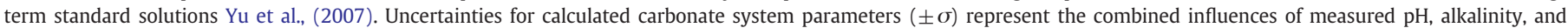
temperature variance during each experiment.

\begin{tabular}{|c|c|c|c|c|c|c|c|c|c|c|c|c|c|c|c|c|}
\hline Experiment & Sample & $\begin{array}{l}\mathrm{T} \\
\left({ }^{\circ} \mathrm{C}\right)\end{array}$ & $\begin{array}{l}\mathrm{S} \\
0 / 00\end{array}$ & $\frac{\mathrm{pH}}{\text { Total }}$ & $\pm 1 \sigma$ & $\begin{array}{l}\text { Alkalinity } \\
\left(\frac{\mu \mathrm{mol}}{\mathrm{kg}}\right)\end{array}$ & $\pm 1 \sigma$ & $\begin{array}{l}\mathrm{CO}_{3}^{2-\mathrm{a}} \\
\left(\frac{\mu \mathrm{mol}}{\mathrm{kg}}\right)\end{array}$ & $\pm 1 \sigma$ & $\begin{array}{l}{[\mathrm{B}]_{S W}} \\
(\mathrm{ppm})\end{array}$ & $\begin{array}{l}B(\mathrm{OH})_{4}^{-\mathrm{a}} \\
\left(\frac{\mu \mathrm{mol}}{\mathrm{kg}}\right)\end{array}$ & $\pm 1 \sigma$ & $\begin{array}{l}\frac{\mathrm{B}(\mathrm{OH})_{4}^{-\mathrm{a}}}{\mathrm{HCO}_{3}^{-}} \\
\left(\mathrm{mol} \mathrm{mol}^{-1}\right)\end{array}$ & $\begin{array}{l}\mathrm{B} / \mathrm{Ca}_{\text {calcite }} \\
\left(\frac{\mu \mathrm{mol}}{\mathrm{mol}}\right)\end{array}$ & $\pm 1 \sigma$ & $\frac{\mathrm{K}_{D}^{\mathrm{a}}}{\times 1000}$ \\
\hline \multirow[t]{2}{*}{ Ambient } & $3 a$ & 22.3 & 33.3 & 8.03 & 0.02 & 2239 & 5 & 182 & 11 & 4.25 & 74 & 5 & 0.041 & 61.5 & 1.6 & 1.48 \\
\hline & $3 b$ & & & & & & & & & & & & & 62.3 & 1.6 & 1.5 \\
\hline \multirow[t]{3}{*}{$\mathrm{T}$} & 1 & 17.7 & 33.2 & 8.12 & 0.03 & 2233 & 21 & 184 & 17 & 4.45 & 82 & 8 & 0.046 & 61.1 & 1.6 & 1.32 \\
\hline & 2 & 19.6 & 33.0 & 8.06 & 0.01 & 2229 & 5 & 175 & 5 & 4.32 & 75 & 4 & 0.042 & 62.9 & 1.6 & 1.50 \\
\hline & 4 & 26.5 & 33.0 & 7.97 & 0.01 & 2237 & 10 & 183 & 6 & 4.45 & 76 & 2 & 0.042 & 64.9 & 1.7 & 1.53 \\
\hline \multirow[t]{3}{*}{$\mathrm{pH}$} & 5 & 22.1 & 33.3 & 7.61 & 0.02 & 2058 & 2 & 72 & 7 & 4.64 & 35 & 3 & 0.019 & 55.7 & 1.4 & 2.97 \\
\hline & 6 & 22.1 & 33.3 & 8.30 & 0.02 & 2425 & 4 & 312 & 24 & 4.48 & 124 & 10 & 0.074 & 69.3 & 1.8 & 0.93 \\
\hline & 7 & 22.1 & 33.3 & 8.67 & 0.03 & 2803 & 7 & 600 & 44 & 4.40 & 200 & 15 & 0.145 & 92.0 & 2.4 & 0.63 \\
\hline \multirow[t]{5}{*}{ S } & $8 a$ & 22.1 & 29.9 & 8.06 & 0.03 & 2040 & 9 & 161 & 16 & 4.21 & 74 & 7 & 0.045 & 55.2 & 1.4 & 1.23 \\
\hline & $8 b$ & & & & & & & & & & & & & 52.9 & 1.4 & 1.17 \\
\hline & $9 a$ & 22.3 & 31.5 & 8.02 & 0.05 & 2163 & 13 & 165 & 27 & 4.43 & 74 & 12 & 0.042 & 66.5 & 1.7 & 1.57 \\
\hline & $9 b$ & & & & & & & & & & & & & 65.0 & 1.7 & 1.54 \\
\hline & 10 & 22.3 & 35.4 & 8.00 & 0.03 & 2385 & 1 & 191 & 19 & 4.80 & 82 & 8 & 0.043 & 71.7 & 1.9 & 1.68 \\
\hline \multirow[t]{2}{*}{ B } & 11 & 22.3 & 32.7 & 7.96 & 0.04 & 2485 & 5 & 157 & 19 & 20.06 & 303 & 40 & 0.162 & 403.8 & 10.5 & 2.49 \\
\hline & 12 & 22.3 & 33.5 & 8.00 & 0.03 & 2915 & 8 & 180 & 13 & 39.92 & 665 & 63 & 0.353 & 899.2 & 23.4 & 2.55 \\
\hline
\end{tabular}

a Calculated values. All others are measured. 
Table 2

Average shell weights and diameters for each experiment.

\begin{tabular}{lllllll}
\hline Experiment & $\begin{array}{l}\text { Shell weight } \\
(\mu \mathrm{g})\end{array}$ & $\pm 1 \sigma$ & $\begin{array}{l}\text { Shell diameter } \\
(\mu \mathrm{m})\end{array}$ & $\pm 1 \sigma$ & $\mathrm{n}$ \\
\hline $3 \mathrm{a}$ & $\begin{array}{l}\text { Ambient } \\
\mathrm{T}\left({ }^{\circ} \mathrm{C}\right)\end{array}$ & 54 & 35 & 571 & 97 & 16 \\
1 & 17.7 & 25 & 24 & 411 & 100 & 19 \\
2 & 19.6 & 24 & 7 & 460 & 58 & 15 \\
4 & 26.5 & 18 & 10 & 430 & 69 & 15 \\
& $\mathrm{pH}($ total $)$ & & & & & \\
5 & 7.6 & 25 & 22 & 478 & 93 & 15 \\
6 & 8.3 & 43 & 31 & 523 & 116 & 15 \\
7 & 8.7 & 33 & 7 & 488 & 42 & 15 \\
& $\mathrm{~S}(\%)$ & & & & & \\
8 & 29.9 & 39 & 29 & 536 & 97 & 20 \\
9 & 31.5 & 54 & 44 & 577 & 151 & 17 \\
10 & 35.4 & 25 & 10 & 443 & 50 & 15 \\
& $\mathrm{~B}(\mathrm{ppm})$ & & & & & \\
11 & 20.1 & 36 & 9 & 528 & 46 & 15 \\
12 & 39.9 & 33 & 33 & 480 & 480 & 16 \\
\hline
\end{tabular}

adsorbed ions. The low weight (5-10\%, Spero and Parker, (1985)) and extreme fragility of juvenile calcite mean that its contribution to bulk shell chemistry (especially after sonication, rinsing and cleaning) was likely minimal (Table 2 ).

Elemental analyses were carried out in the Godwin Laboratory at Cambridge University following the methods of Yu et al. (2006). Calcium concentrations were first measured by Inductively-Coupled Plasma Atomic Emission Spectrometry (ICP-AES). Aliquots of the same solution were diluted to $100 \mathrm{ppm}$ [Ca] to minimize matrix effects during subsequent analysis by Inductively-Coupled Plasma Mass Spectrometry (ICP-MS, PerkinElmer SCIEX Elan DRC II). Standards prepared with Milli- $\mathrm{Q}^{+}$allowed a $\mathrm{B} / \mathrm{Ca}$ detection range of 0-260 $\mu \mathrm{mol} \mathrm{mol}^{-1}$, after Yu et al. (2007). Standard solutions were measured every 3-5 samples, and the long-term (2 yr) relative standard deviation (RSD, $1 \sigma$ ) for $\mathrm{B} / \mathrm{Ca}$ is $2.6 \%$ (Cambridge in-house elemental standard). Boron memory effect was reduced by use of a quartz spray chamber and long wash-out times, and drift was corrected using external standards.

Boron concentrations in experimental seawater were also measured by ICP-MS. Seawater samples $(15 \mu \mathrm{l})$ were taken from each experiment, filtered at $0.2 \mu \mathrm{m}$, acidified with $0.5 \mu \mathrm{l} 15 \mathrm{~N} \mathrm{HCl}$, and stored in nalgene bottles sealed with parafilm. Samples were analyzed 6 months later at Cambridge on the same instrument as the foraminiferal calcite. Prior to analysis, $10 \mu \mathrm{l}$ of seawater was diluted $500 \times$ in a solution of $1 \%$ quartz-distilled $\mathrm{HNO}_{3}$ and internal standard (1 ppb Rhodium, Indium), which was used to correct for drift. During the run, RSD of the internal standard was $2.3 \%$ (Rh) and $1.4 \%$ (In).

\subsection{Laser ablation ICP-MS}

Element profiles were measured at The Australian National University in Canberra with a pulsed ArF excimer laser $(\lambda=193 \mathrm{~nm})$ coupled to an Agilent $7500 \mathrm{~s}$ inductively coupled plasma mass spectrometer (ICP-MS), following previously-described procedures (Eggins et al., 2002; Eggins et al., 2003). Two foraminifers per experiment were split in half and treated with an oxidative solution of $50 \%$ analytical-grade $\mathrm{H}_{2} \mathrm{O}_{2}$ buffered with $0.001 \mathrm{~N} \mathrm{NaOH}$ to remove residual organic matter. Pre-analysis SEM photos of the inner shell surface indicated that the juvenile portion of the shell was not present in most specimens selected for laser ablation. Any juvenile calcite remaining on the few shells where it was observed was removed by the cleaning procedure prior to ablation. Cleaned and Milli- $Q$ rinsed shell halves were then mounted on carbon tape and profiled 2-4 times each, perpendicular to the shell surface. Multiple element profiles from each specimen were then matched via the Linage function in Analyseries 2.0 (Paillard and Yiou, 1996) and then combined into a single average profile. These procedures yielded $\mathrm{B} / \mathrm{Ca}$ and $\mathrm{Mg} / \mathrm{Ca}$ profiles for 25 cultured 0 . universa shells.

\section{Results}

\subsection{Carbonate system}

Ratios of boron to calcium (B/Ca) measured via ICP-MS are presented in Fig. 1 and Table 1. Between pH 7.6 and 8.7 (total scale), B/Ca in cultured 0 . universa shells increases from $56 \pm 1$ to $92 \pm 2 \mu \mathrm{mol} \mathrm{mol}{ }^{-1}$. This experimental $\mathrm{pH}$ range corresponds to ranges of $70-577 \mu \mathrm{mol}\left[\mathrm{CO}_{3}^{2-}\right]$ and 33-195 $\mu \mathrm{mol}\left[\mathrm{B}(\mathrm{OH})_{4}^{-}\right]$.

Because several seawater parameters are physically and chemically linked, some of our experiments varied more than one parameter. For example, temperature influences the carbonate system equilibrium constants $\mathrm{K}_{1}$ and $\mathrm{K}_{2}$, leading to slightly lower $\mathrm{pH}$ at higher temperature. At 17.7 and $26.5^{\circ} \mathrm{C}$, pH was 8.1 and 8.0 (total scale), respectively, creating a pH gradient of $0.1 \pm 0.03$ units. Impact of this difference on the $\mathrm{B} / \mathrm{Ca}$-temperature results is discussed later. Other carbonate system parameters gave small differences across the temperature range: $4 \pm 23 \mu \mathrm{mol} \mathrm{kg}{ }^{-1}$ alkalinity, $1 \pm$ $10 \mu \mathrm{mol} \mathrm{kg}{ }^{-1}$ carbonate ion, and $10 \pm 23 \mu \mathrm{mol} \mathrm{kg}{ }^{-1}$ dissolved inorganic carbon, or DIC ( \pm root mean square error). It is also important to note that adding acid or base to seawater simultaneously changes $\mathrm{pH}$, carbonate ion, and alkalinity. Thus we will refer to these as "carbonate system" experiments rather than "pH" experiments. Alkalinity and $\mathrm{CO}_{3}^{2-}$ differences between the lowest and highest $\mathrm{pH}$ seawater (7.7-8.7) were $745 \pm 7$ and $527 \pm 24 \mu \mathrm{mol} \mathrm{kg}{ }^{-1}$, respectively, due to changes in aqueous speciation. However, no carbon was added to
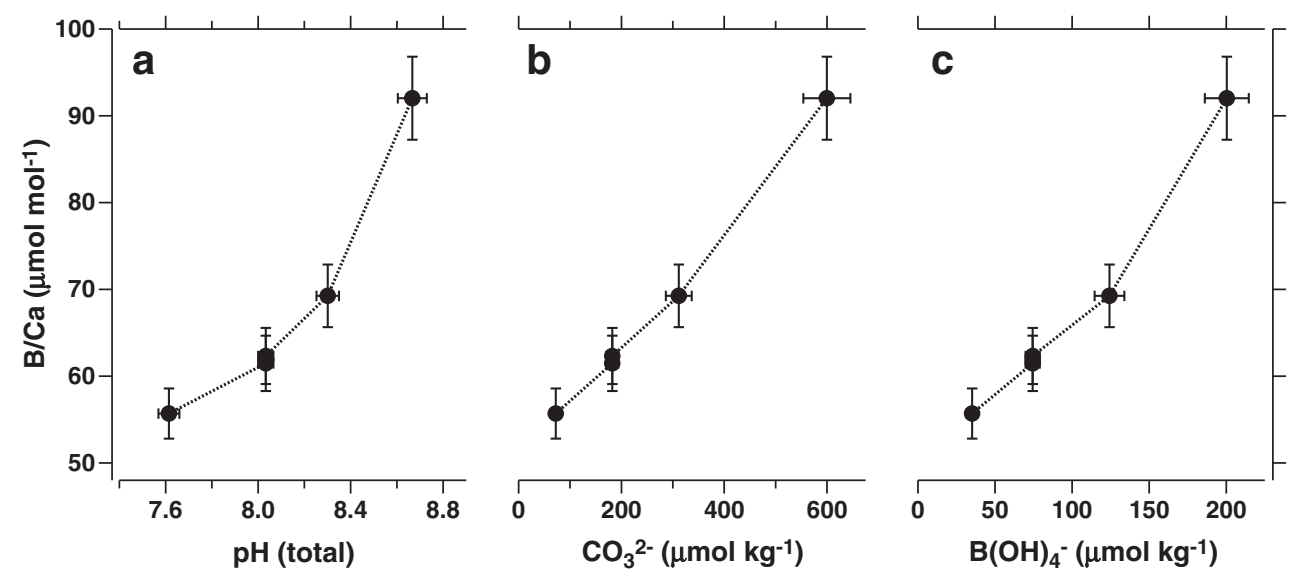

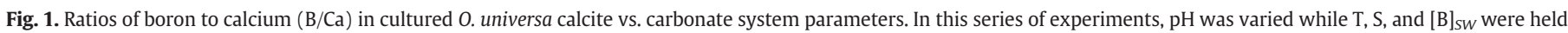
constant. The same B/Ca data are plotted against different parameters: $\mathrm{pH}(\mathrm{a})$, carbonate ion (b), and borate (c). Error bars are $\pm 2 \sigma$. 


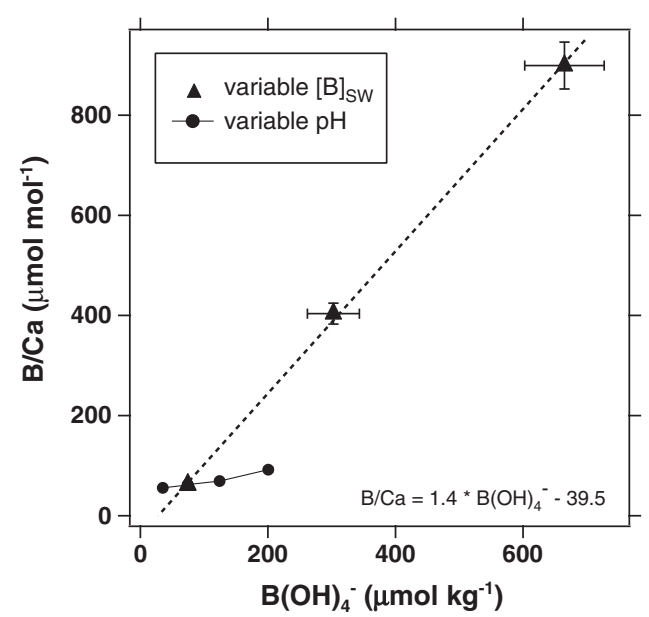

Fig. 2. In carbonate system experiments (circles), total $[\mathrm{B}]_{s W}$ is held constant and the concentration of borate increases with $\mathrm{pH}$ due to a $\mathrm{pH}$-driven shift in aqueous speciation. By contrast, in $[\mathrm{B}]_{S W}$ experiments (triangles), $\mathrm{pH}$ is held constant $(\mathrm{pH}=7.99 \pm 0.03$ and $\mathrm{CO}_{3}^{2-}=167 \pm 11$ ) and the activity of borate simply increases with total $[\mathrm{B}]_{S W}$. For a given borate increase, the corresponding $\mathrm{B} / \mathrm{Ca}$ increase in 0 . universa calcite is $\sim 5 \times$ higher in $[\mathrm{B}]_{S W}$ than in carbonate system experiments. This might be due to aqueous complexation or competition with other ions. Error bars are $\pm 2 \sigma$.

seawater by adding $\mathrm{HCl}$ or $\mathrm{NaOH}$, so the DIC difference across our $\mathrm{pH}$ range was negligible $\left(0.2 \pm 17.7 \mu \mathrm{mol} \mathrm{kg}^{-1}\right)$ and driven by gas exchange during water transfer and feeding. Finally, between our lowest and highest salinity experiments (29.9-35.4), carbonate system differences were: $0.05 \pm 0.04 \mathrm{pH}$ units, $345 \pm 9 \mu \mathrm{mol} \mathrm{kg} \mathrm{kg}^{-1}$ alkalinity, $310 \pm 18 \mu \mathrm{mol} \mathrm{kg}{ }^{-1}$ DIC, and $31+/-13 \mu \mathrm{mol} \mathrm{kg}{ }^{-1} \mathrm{CO}_{3}^{2-}$.

\subsection{Boron concentration}

B/Ca increases linearly with boron in seawater (Fig. 2), and can be described by the following equations:

$\mathrm{B} / \mathrm{Ca}=23.4 *[\mathrm{~B}]_{S W}-43.4 \quad\left(R^{2}=0.99, \mathrm{n}=4\right)$

$\mathrm{B} / \mathrm{Ca}=1.4 *\left[\mathrm{~B}(\mathrm{OH})_{4}^{-}\right]-39.5\left(R^{2}=0.99, \mathrm{n}=4\right)$

where $[\mathrm{B}]_{S W}$ is the measured concentration of boron in seawater $(\mathrm{ppm})$ and $\left[\mathrm{B}(\mathrm{OH})_{4}^{-}\right]$is calculated from $\mathrm{pH}$ and $\mathrm{K}_{B}$ (Dickson, 1990).
While higher salinity should concentrate all major dissolved elements equally (i.e., both $\mathrm{B}$ and $\mathrm{Ca}$ ), our high-[B] experiments increased $[\mathrm{B}]$ alone. These experimental conditions differed from ambient conditions most dramatically with respect to $[\mathrm{B}]_{S W}$ (raised 400 and $900 \%$, to 2036 and $4070 \mu \mathrm{mol} \mathrm{B} \mathrm{kg}^{-1}$ seawater, respectively) but total alkalinity also increased 11 and 30\% due to the added boron alkalinity. Other parameters ( $\mathrm{pH}$, temperature, salinity) were held constant. The response of $\mathrm{B} / \mathrm{Ca}$ to $\left[\mathrm{B}(\mathrm{OH})_{4}^{-}\right]$in these $[\mathrm{B}]_{S W}$ experiments (Eq. 5 ) is $\sim 5 \times$ stronger than in carbonate system experiments, where $\left[\mathrm{B}(\mathrm{OH})_{4}^{-}\right]$increased due to a shift in speciation rather than a rise in $[\mathrm{B}]_{S W}$ (Fig. 2).

\subsection{Salinity and temperature}

B/Ca increases from 55 to $72 \mu \mathrm{mol} \mathrm{mol}{ }^{-1}$ between salinity 29.9 and 35.4 (Fig. 3). A linear least-squares fit gives: $\mathrm{B} / \mathrm{Ca}=2.6 * \mathrm{~S}-20.6$ $\left(R^{2}=0.6\right)$. This relationship is significant at a $95 \%$ confidence level as determined by the Student's $t$-test $(n=7, t>1.90)$. The temperature$\mathrm{B} / \mathrm{C}$ a relationship between 17.7 and $26.5^{\circ} \mathrm{C}$, however, is not significant at a $95 \%$ confidence level $(n=5, t<2.57)$.

\subsection{Laser ablation profiles}

Individual shell profiles reveal variable element patterns. Even specimens grown under identical experimental conditions exhibit different cross-sectional trends and micro-scale $\mathrm{B} / \mathrm{Ca}$ to $\mathrm{Mg} / \mathrm{Ca}$ relationships (Fig. 4a and b). Given the small number of individuals analyzed per experiment ( $\mathrm{n}=1$ to 3 ), it is unlikely that we have captured the full range of variability in this species. Despite the observed intra-shell variation, we find that in 21 out of the 25 analyzed specimens, $\mathrm{B} / \mathrm{Ca}$ increases from the inner to the outer surface of the shell. Furthermore, although the absolute maximum and minimum ratios vary, the total $\mathrm{B} / \mathrm{Ca}$ range within each shell is consistently between 40 and $60 \mu \mathrm{mol} \mathrm{mol}{ }^{-1}$ even across different experiments ( $\mathrm{pH}$, salinity, etc.). Some profiles also exhibit an inverse relationship between $\mathrm{B} / \mathrm{Ca}$ and $\mathrm{Mg} / \mathrm{Ca}$ (Fig. $4 \mathrm{c}$ and d).

\section{Discussion}

In our culture experiments, the carbonate system exerts a measurable control on B/Ca (Fig. 1) of O. universa. Our results are broadly consistent with the existing theoretical framework proposed for the proxy, because $\mathrm{B} / \mathrm{Ca}$ does increase with aqueous borate concentration. However, because $\left[\mathrm{B}(\mathrm{OH})_{4}^{-}\right],\left[\mathrm{B}(\mathrm{OH})_{4}^{-} / \mathrm{HCO}_{3}^{-}\right], \mathrm{pH}$ and $\left[\mathrm{CO}_{3}^{2-}\right]$ covary in our carbonate system experiments, it remains
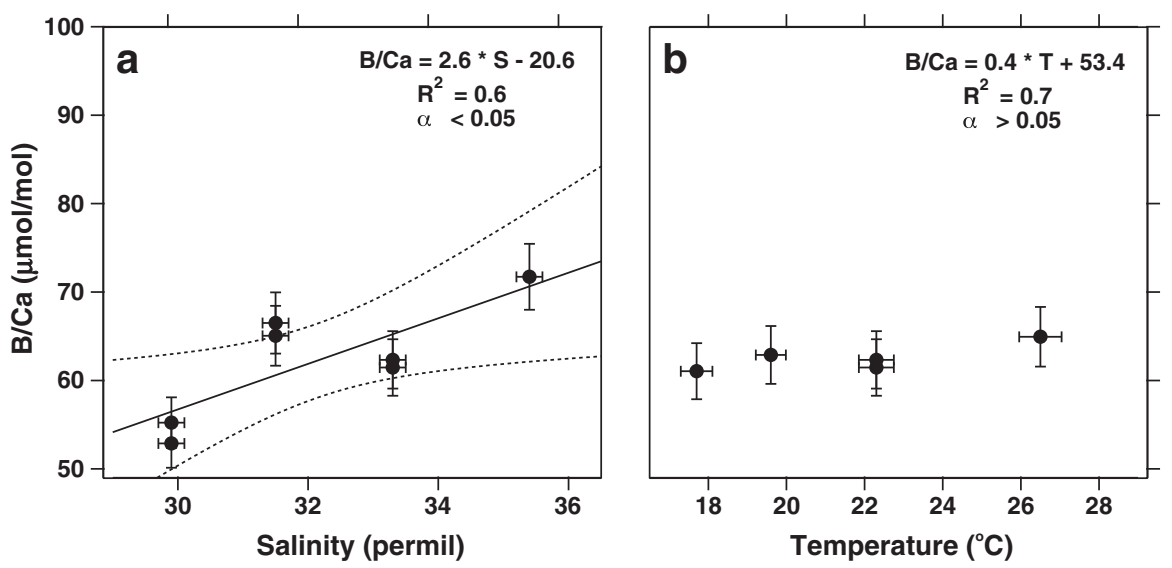

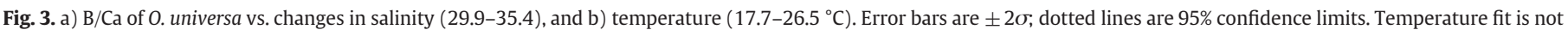
shown because although the $R^{2}$ seems high, its slope is not statistically different from zero $(\alpha>0.05)$. 

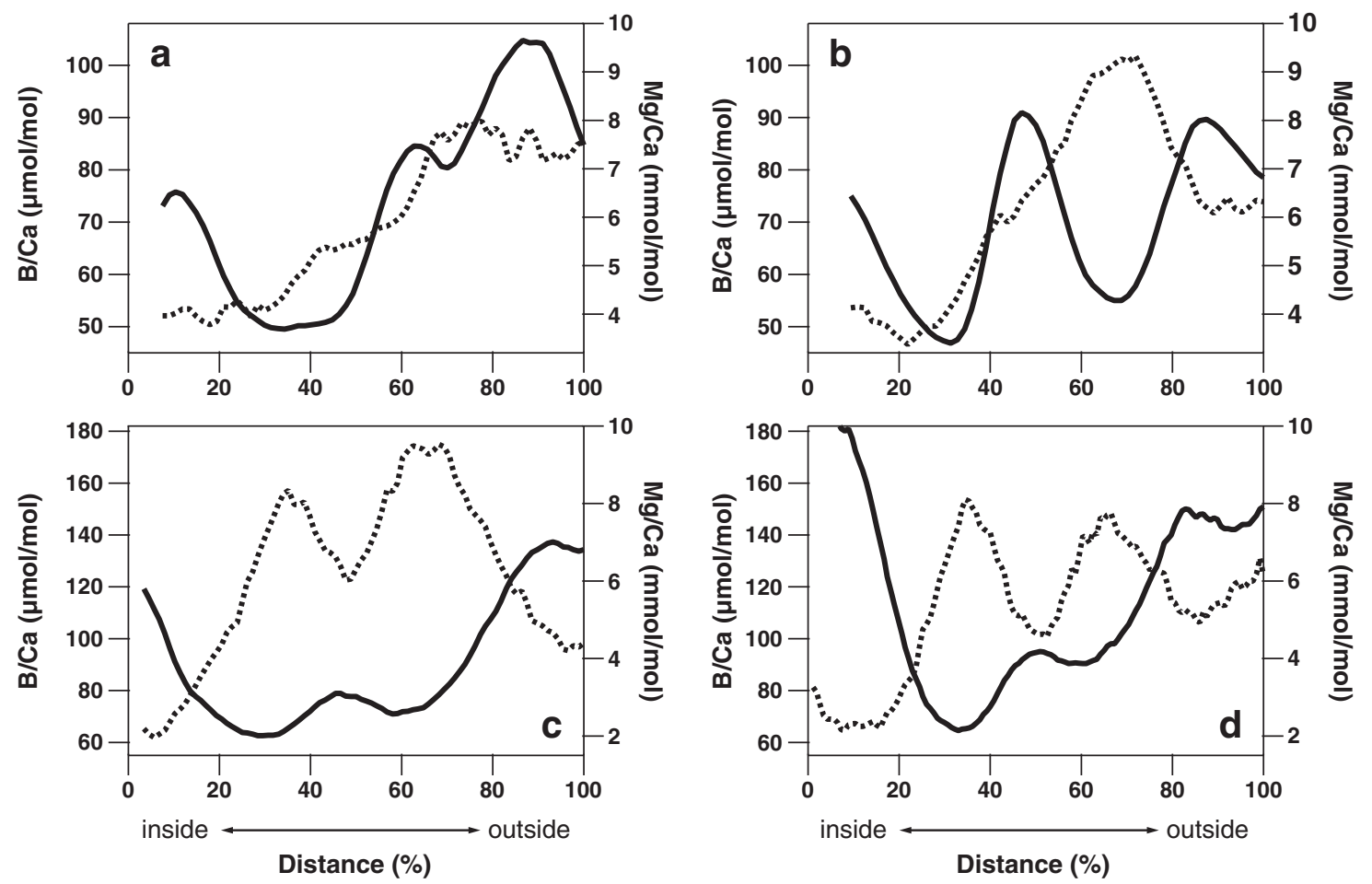

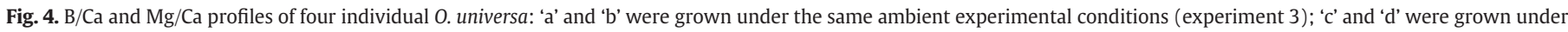
high $\mathrm{pH}$ conditions (experiment 7). Thick line is $\mathrm{Mg} / \mathrm{Ca}$; dotted line is $\mathrm{B} / \mathrm{Ca}$. Profiles are plotted against \% distance from the inner shell surface (estimated from ablation time).

unclear which is truly the controlling parameter. In addition, we see that salinity and seawater boron concentration $\left([\mathrm{B}]_{S W}\right)$ exert an influence on $\mathrm{B} / \mathrm{Ca}$. A deeper understanding of the relative influences of these and other possible controls is needed to accurately interpret $\mathrm{B} / \mathrm{Ca}$ from paleo-records. Here, we discuss new insights gained into $B$ incorporation with the aim of clarifying the proxy's theoretical framework and eventually resolving discrepancies between existing core-top datasets.

\subsection{Sensitivity to the carbonate system in culture experiments}

Eq. 1 suggests that calcite grown from solutions with greater B $(\mathrm{OH})_{4}^{-}$should have higher $\mathrm{B} / \mathrm{Ca}$, all else being equal, and this prediction holds true in our carbonate system experiments (Figs. 1 and 2). Interestingly, we see the partition coefficient $\left(K_{D}\right.$, Eq. 3) decreasing at higher $\mathrm{pH}$, suggesting less efficient incorporation of $\mathrm{B}$ into calcite (Fig. 5). In other words, although the absolute B/Ca values are increasing, for a given $\mathrm{B}(\mathrm{OH})_{4}^{-} / \mathrm{HCO}_{3}^{-}$ratio less $\mathrm{B}$ is incorporated into calcite at high $\mathrm{pH}$ than at low $\mathrm{pH}$. To understand this behavior, we compare different culture experiments and consider several possible controls below.

In our culture experiments, we increase $\left[\mathrm{B}(\mathrm{OH})_{4}^{-}\right]$in two separate ways: (1) by raising $\mathrm{pH}$, which shifts $\mathrm{B}$ speciation in favor of $\mathrm{B}(\mathrm{OH})_{4}^{-}$ while the total amount of $\mathrm{B}$ dissolved in seawater $\left([\mathrm{B}]_{S W}\right)$ is held constant, and (2) by raising $[\mathrm{B}]_{S W}$, which increases both $\mathrm{B}(\mathrm{OH})_{4}^{-}$and $\mathrm{B}$ $(\mathrm{OH})_{3}$, while $\mathrm{pH}$ is held constant. Interestingly, the $\mathrm{B} / \mathrm{Ca}$ response of $O$. universa to increased $\mathrm{B}(\mathrm{OH})_{4}^{-}$is $\sim 5 \times$ stronger when $[\mathrm{B}]_{S W}$ is changed than when $\mathrm{pH}$ is changed (Fig. 2). The weaker response of $\mathrm{B} / \mathrm{Ca}$ to borate raised by base addition (rather than by $[\mathrm{B}]_{S W}$ ) may be caused by: A) an increasingly negatively-charged calcite surface at higher $\mathrm{pH}$, making it more difficult for borate to adsorb (Morse, 1986; van Cappellen et al., 1993), and/or B) the involvement of other $\mathrm{pH}$ sensitive ions in calcification. Our data cannot be used to address possibility A, but we will discuss B in the sections below. Specifically, we will consider the potential roles of boric acid and carbonate ions.

\subsection{The role of boric acid}

The boron isotopic composition of 0 . universa calcite falls close to the isotopic composition of borate in seawater, suggesting preferential incorporation of borate (Foster, 2008; Foster et al., 2010; Hemming and Hanson, 1992; Hönisch et al., 2007). However, empirical boron isotope calibration curves involving biogenic and inorganic carbonates grown over a wide $\mathrm{pH}$ range in the laboratory (Hönisch and Hemming, 2004; Krief et al., 2010; Sanyal et al., 1996; Sanyal et al., 2000; Sanyal et al., 2001) have shallower slopes than expected from the measured boron isotope fractionation between dissolved boric acid and borate in seawater (Klochko et al., 2006). Because carbonates do not strictly follow the expected isotopic composition of $\mathrm{B}(\mathrm{OH})_{4}^{-}$in solution, Klochko et al. (2009) have suggested that some $\mathrm{B}(\mathrm{OH})_{3}$ may also be incorporated at low $\mathrm{pH}$. Since $\mathrm{B}(\mathrm{OH})_{3}$ is isotopically heavier (i.e. has higher ${ }^{11} \mathrm{~B} /{ }^{10} \mathrm{~B}$ ) than $\mathrm{B}(\mathrm{OH})_{4}^{-}$, its incorporation at lower $\mathrm{pH}$ might explain the unexpectedly high $\delta^{11} \mathrm{~B}$ of carbonates (Fig. 6). Similarly, $\mathrm{B}(\mathrm{OH})_{3}$ incorporation might also explain the elevation of our lowest-pH B/Ca ratio above the value predicted by the [B] experiments (Eq. 5, Fig. 7).

Assuming end-member values for boric acid and borate as predicted by the measured fractionation factor $\varepsilon=27.2 \%$ (Klochko et al., 2006) and using the empirical $\delta^{11} \mathrm{~B}$ calibration for O. universa (Sanyal et al., 1996), we can apply an isotope mass-balance calculation to estimate how much isotopically heavy boric acid would have to be incorporated to explain the unexpectedly high $\delta^{11} \mathrm{~B}$ of carbonates at lower $\mathrm{pH}$ (Fig. 6). The calculated boric acid contribution to total $[\mathrm{B}]$ in cultured 0 . universa calcite is only 3-8\%, exerting a small effect on $\mathrm{B} / \mathrm{Ca}\left(4.4-2.1 \mu \mathrm{mol} \mathrm{mol}{ }^{-1}\right)$ and a negligible effect on $K_{D}$ (Fig. 5). These results support dominant incorporation of $\mathrm{B}(\mathrm{OH})_{4}^{-}$(Hemming et al., 1995; Hemming and Hanson, 

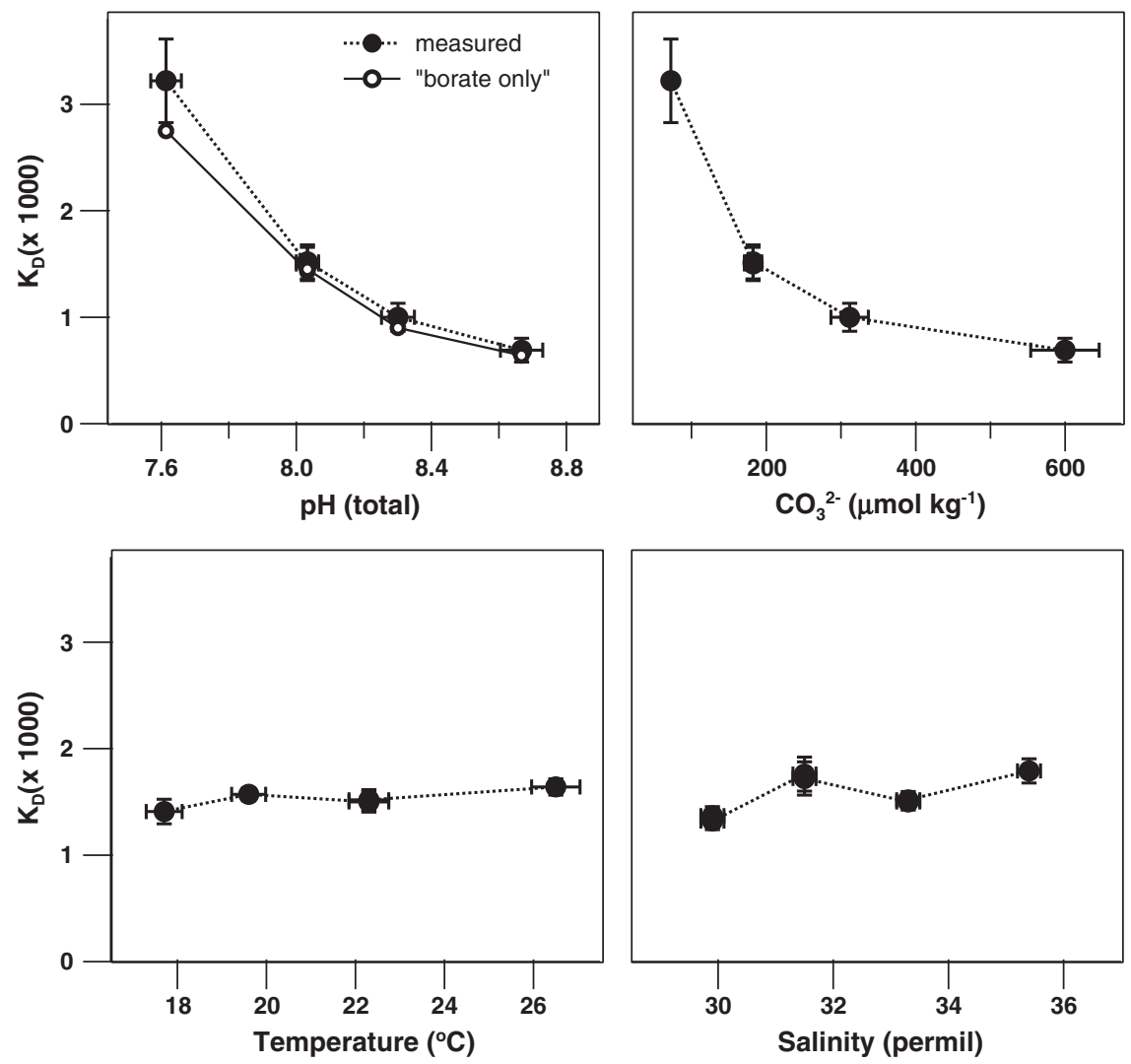

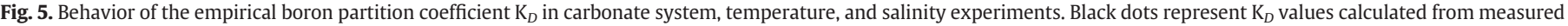

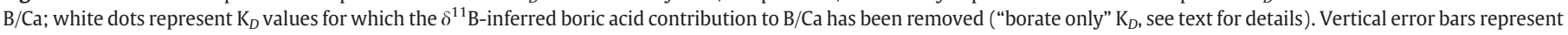

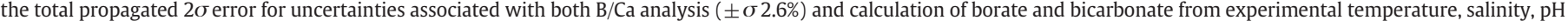
and alkalinity measurements.

1992; Sen et al., 1994) rather than a significant contribution of $\mathrm{B}(\mathrm{OH})_{3}$ (Klochko et al., 2009) and are also consistent with evidence for exclusive borate incorporation from benthic species (Rae et al., 2011). One puzzling observation is that the empirical $\delta^{11} \mathrm{~B}-\mathrm{pH}$ calibration for 0 . universa cannot be completely explained by mixtures of borate and boric acid because the highest measured isotope value at $\mathrm{pH} 8.9$ (total scale) falls below the $\delta^{11} \mathrm{~B}$ of borate (outside the two endmembers), and suggests either an analytical offset or an unidentified fractionation process during calcification such as kinetic or biologic effects. We conclude that despite remaining uncertainties, the isotope data of Sanyal et al. (1996) suggest that incorporation of boric acid must be small and we must instead turn to other explanations for observed B/Ca behavior.

\subsection{The role of carbonate ion}

Another possible explanation for observed $\mathrm{B} / \mathrm{Ca}$ behavior lies in the role of $\left[\mathrm{CO}_{3}^{2-}\right]$ during calcification. If aqueous $\mathrm{B}(\mathrm{OH})_{4}^{-}$and $\mathrm{CO}_{3}^{2-}$ compete for the same lattice site (Sen et al., 1994), and carbonate ions are increasingly used in foraminiferal calcification at higher $\mathrm{pH}$, then $\mathrm{B}(\mathrm{OH})_{4}^{-}$incorporation may correspondingly become less favorable. This idea is supported by a comparison of the predicted and observed B/ Ca curves shown in Fig. 7. The predicted values are derived from the relationship between $\mathrm{B} / \mathrm{Ca}$ and $\mathrm{B}(\mathrm{OH})_{4}^{-} / \mathrm{HCO}_{3}^{-}$observed in $[\mathrm{B}]_{S W}$ experiments, where $\mathrm{pH}=7.99 \pm 0.03$ and $\mathrm{CO}_{3}^{2}-167 \pm 11$. Because $\mathrm{pH}$ and $\mathrm{CO}_{3}^{2-}$ were held constant in those experiments, we may assume the dominant influence on $\mathrm{B} / \mathrm{Ca}$ was a purely $[\mathrm{B}]_{S W}$-driven parameter, in this case $\mathrm{B}(\mathrm{OH})_{4}^{-} / \mathrm{HCO}_{3}^{-}$. By contrast, in carbonate system experiments, $\mathrm{pH}$ and $\mathrm{CO}_{3}^{2-}$ both increase, and we see lower $\mathrm{B} / \mathrm{Ca}$ values than predicted from increasing $\mathrm{B}(\mathrm{OH})_{4}^{-} / \mathrm{HCO}_{3}^{-}$alone. This may indicate competition with another ion whose abundance also increases with $\mathrm{pH}$, such as $\mathrm{CO}_{3}^{2-}$

Greater incorporation of $\mathrm{CO}_{3}^{2-}$ at higher $\mathrm{pH}$ has already been proposed to explain carbon and oxygen isotope values measured in 0 . universa (Spero et al., 1997; Zeebe, 1999). Carbon and oxygen isotope compositions of foraminiferal calcite are influenced by the proportion of $\mathrm{CO}_{3}^{2-}$ and $\mathrm{HCO}_{3}^{-}$used during calcification because $\mathrm{CO}_{3}^{2-}$ is more enriched in the lighter isotopes of carbon and oxygen than $\mathrm{HCO}_{3}^{-}$. Precipitation experiments that change solution $\left[\mathrm{CO}_{3}^{2}{ }^{-}\right]$while holding $\mathrm{pH}$ constant could be conducted to test the hypothesis of competition between $\mathrm{B}(\mathrm{OH})_{4}^{-}$and $\mathrm{CO}_{3}^{2-}$. B/Ca of the polar foraminiferan Neogloboquadrina pachyderma (sinistral) may also respond to $\mathrm{CO}_{3}^{2-}$ (Hendry et al., 2009), suggesting that this phenomenon may not be limited to 0 . universa.

\section{4. $\mathrm{B} / \mathrm{Ca}$ variability within individual shells}

Laser ablation profiles of individual shells have revealed that foraminiferal calcite is compositionally heterogeneous, and that the magnitude of observed $\mathrm{Mg} / \mathrm{Ca}$ variability exceeds what could be explained by temperature changes due to vertical water column migration (Eggins et al., 2003; Eggins et al., 2004). Similarly, the B/Ca heterogeneity observed in our culture experiments (Fig. 4) cannot be explained by changes in seawater composition or temperature because these were held constant within each experimental group. Light was the only experimental parameter that varied on a diurnal basis ( $12 \mathrm{~h}$ of constant light alternating with $12 \mathrm{~h}$ of constant darkness throughout each experiment), yet in some specimens we see many alternating bands of high and low B/Ca. Understanding possible controls on such intra-shell variation is important to proxy 

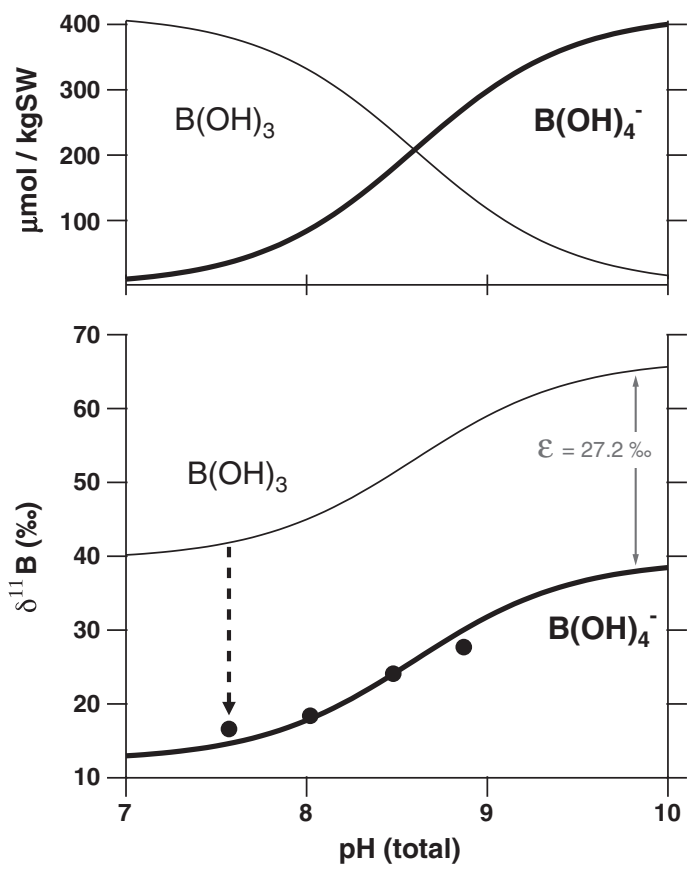

Fig. 6. Speciation (top) and isotopic composition (bottom) of dissolved borate in seawater both change with $\mathrm{pH}$. Because bonds in borate and boric acid are characterized by different vibrational frequencies, boric acid is isotopically heavier than borate by $27.2 \%$ (Klochko et al., 2006). Klochko et al., (2009) have suggested that at low pH, incorporation of boric acid into calcite could explain higher-than-expected boron isotope values. A simple mixing line drawn between boric acid and borate shows that the $\delta^{11} \mathrm{~B}$ of cultured 0 . universa (black dots, Sanyal et al., (1996)) could be explained by incorporation of 3-8\% boric acid (below $\mathrm{pH} 8$ ), but the value of the highest $\mathrm{pH}$ calibration point falls below the predicted borate curve. See text for further discussion.

development because changes in processes that control the banding could also influence the overall relationship between shell and seawater chemistry. To apply modern calibrations to past environments, we need to identify and evaluate the influence of such additional controls.

As an individual 0 . universa ages, its symbiotic dinoflagellates divide and increase in number (Spero and Parker, 1985). Assuming

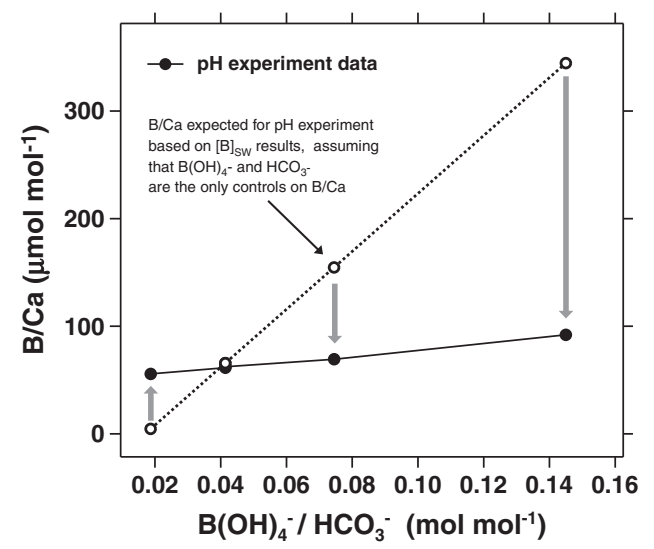

Fig. 7. B/Ca values observed in our carbonate system experiments do not agree with values predicted in accordance with the current $\mathrm{B}$ incorporation model. Predicted $\mathrm{B} / \mathrm{Ca}$ values (white circles) were derived by applying the $\mathrm{B} / \mathrm{Ca}-\mathrm{B}(\mathrm{OH})_{4}^{-} / \mathrm{HCO}_{3}^{-}$relationship observed in $[\mathrm{B}]_{S W}$ experiments to $\mathrm{B}(\mathrm{OH})_{4}^{-} / \mathrm{HCO}_{3}^{-}$values calculated for each carbonate system experiment. Thus, the predicted values reflect what the $\mathrm{B} / \mathrm{Ca}$ would be if $\mathrm{B}$ $(\mathrm{OH})_{4}^{-} / \mathrm{HCO}_{3}^{-}$were the only control on $\mathrm{B} / \mathrm{Ca}$. The mismatch between predicted and observed $\mathrm{B} / \mathrm{Ca}$ in our carbonate system experiment series thus suggests that other $\mathrm{pH}$ sensitive ions may be involved in calcification. that most calcite is added progressively on the sphere's outer surface (Lee and Anderson, 1991; Spero, 1988), observed increases in $\mathrm{B} / \mathrm{Ca}$ from the inner to the outer shell could be caused by increasing numbers of photosynthetic symbionts progressively removing more $\mathrm{CO}_{2}$ from the microenvironment during a foraminifer's lifetime. This would raise local pH and carbonate ion (Hönisch et al., 2003; Rink et al., 1998), either or both of which increase B/Ca (Fig. 1). In some profiles, $\mathrm{B} / \mathrm{Ca}$ decreases slightly at the outer shell edge, perhaps reflecting symbiont rejection immediately before gametogenesis. However, low symbiont abundance or absence the day before gametogenesis was only observed for half of these specimens, so the control on this pattern remains unclear.

Photosynthesis, respiration, and calcification all occur during the day, but at night photosynthesis ceases while the other two processes continue. Transition between these regimes can create a day-night shift of $\sim 1 \mathrm{pH}$ unit in the microenvironment (Rink et al., 1998), though this diurnal $\mathrm{pH}$ range may vary with specimen size and number of symbionts. Applying our calibration to Rink's measured day-night $\mathrm{pH}$ ranges predicts a $\mathrm{B} / \mathrm{Ca}$ range of $\sim 40 \mu \mathrm{mol} \mathrm{mol}^{-1}$. Assuming that our bulk $\mathrm{B} / \mathrm{Ca}-\mathrm{pH}$ trend is applicable to individual calcification bands, the average $\sim 60 \mu \mathrm{mol} \mathrm{B} / \mathrm{Ca}$ range observed in banded profiles might be partially explained by diurnal microenvironment changes. However, even though all cultured specimens possessed symbionts and should have endured large diurnal $\mathrm{pH}$ shifts, some individuals did not exhibit any diurnal B/Ca variability, which does not support a symbiont-driven $\mathrm{B}$ incorporation pattern.

Although wide variability within our dataset prevents a clear explanation of shell heterogeneity (Fig. 4), our results raise two important points. One is that individual specimens grown under identical conditions may have different intrashell element profiles. This highlights the need to combine multiple specimens when applying trace element proxies to paleoceanographic applications. The second point is that any distribution coefficient derived from bulk shell measurements averages these different compositional bands. Bulk shell measurements may still largely reflect external seawater conditions, but it is important to acknowledge that any seawater influence on $\mathrm{B} / \mathrm{Ca}$ must first pass through a variable biological and microenvironment filter.

\subsection{Influence of $[B]_{S W}$ on partition coefficients}

Another tool for examining calcite precipitation chemistry is the empirical partition coefficient, or D value $\left(\mathrm{D}_{B}=[\mathrm{B} / \mathrm{Ca}]_{\text {solid }} /[\mathrm{B} / \mathrm{Ca}]_{\text {solution, }}\right.$, cf. (Morse and Bender, 1990)). In our study, $D_{B} \approx 1.5 \times 10^{-3}$ in ambient seawater. If this $D_{B}$ were applicable at higher $[\mathrm{B}]_{S W}$, then the measured $\mathrm{B} / \mathrm{Ca}$ of calcite grown in higher-[B] solutions should equal $\mathrm{D} \times[\mathrm{B} / \mathrm{Ca}]_{S W}$. To test this, we calculate $[\mathrm{B} / \mathrm{Ca}]_{S W}$ by dividing experimental seawater $\mathrm{B}$ concentrations (measured by ICP-MS, Table 1 ) by Ca (assumed to scale with salinity according to Dickson et al. (2007); Riley and Tongudai, (1967)), and then multiply this ratio by the D value determined from our ambient seawater experiment. For calcite grown in seawater with 20 and $40 \mathrm{ppm} \mathrm{B}$, this predicts B/Ca values of $297 \mu \mathrm{mol} \mathrm{mol}{ }^{-1}$ and $578 \mu \mathrm{mol} \mathrm{mol}^{-1}$, respectively. Instead, calcite from our 20 and $40 \mathrm{ppm}$ $\mathrm{B}$ experiments has higher $\mathrm{B} / \mathrm{Ca}$ values of 404 and $899 \mu \mathrm{mol} \mathrm{mol}^{-1}$, resulting in $\mathrm{D}$ values of $2.1 \times 10^{-3}$ and $2.4 \times 10^{-3}$, respectively. The reason for excess $\mathrm{B} / \mathrm{Ca}$ enrichment at elevated boron seawater concentrations is not clear.

$\mathrm{Ni}$ et al. (2007) have suggested a calcification-rate control on $\mathrm{B} / \mathrm{Ca}$ of G. sacculifer and G. ruber based on shell size trends, with higher B/Ca in larger specimens. Because the observations of $\mathrm{Ni}$ et al. were not made on Orbulina, it is not clear whether the suggested controls are applicable to our results. Because all shells from each experiment needed to be combined to make a sample large enough for ICP-MS analysis, we could not evaluate the shell size-B/Ca relationship. Even if separation by shell size had been possible, it would have been very difficult to quantify actual calcification rates, which may vary 
throughout the life of a foraminifer. Calcite saturation $(\Omega)$ in our different $[\mathrm{B}]$ experiments are the same within uncertainty $(2 \sigma)$, so it seems that elevated calcification rates and preferential incorporation of elements closer to seawater ratios (Morse and Bender, 1990) are not a likely explanation. Alternatively, the $\mathrm{B} / \mathrm{Ca}$-size relationship observed by Ni et al. (2007) may be related to the depth(s) at which individual foraminifers calcify. Laboratory and field studies have linked higher light levels with increased symbiont photosynthesis and enhanced calcification (Bé, 1972; Hönisch and Hemming, 2004; Spero et al., 2003), suggesting that larger individuals grow at shallower depths. If symbiont activity in larger G. sacculifer and G. ruber from the $\mathrm{Ni}$ et al. study were higher than in smaller individuals, the local $\mathrm{pH}$ and $\mathrm{B}(\mathrm{OH})_{4}^{-}$might also have been higher, making conditions favorable for greater $B$ incorporation. This possible control could be tested both with plankton tow and laboratory-based light experiments.

Another possible explanation for the unexpected B partitioning observed in our culture experiments may be a modified crystal habit occurring in experimental solutions with greater than $4 \mathrm{ppm} \mathrm{B}$ (Hemming et al., 1995). The appearance of a heavily-striated calcite form with more rounded growth steps such as that observed by Hemming et al. (1995) at high $[\mathrm{B}]_{s W}$ may present a surface more conducive to B adsorption and incorporation. Finally, we note that although $\mathrm{D}$ has provided insight into trace element behavior in other studies (Elderfield et al., 1996), it may not be as applicable in this case if $\mathrm{B}$ and $\mathrm{Ca}$ are built into different lattice sites with different size/ charge requirements, and are not directly competing with each other or with the same types of ions in solution.

\subsection{Salinity}

Our salinity (S) experiments span most of the natural growth range for O. universa, except very high-salinity habitats like the Red Sea and the Mediterranean (up to $\sim 40$ ). Experimental seawater boron concentrations measured by ICP-MS indicate that the B/Salinity ratio of our experimental seawater differs from the average modern ocean value (0.1336, (Lee et al., 2010)) by a maximum of $5.1 \%$ and an average of $2.6 \%$ (Table 1). We do not consider this to indicate significant B contamination from glass culture jars either through leaching or adsorption. In addition, the ratio of boron to salinity measured for the high salinity experiment was slightly higher than would be predicted from Lee et al. (2010), suggesting that boron was not lost through boric acid volatilization.

These results show that when salinity is raised by evaporation, $[\mathrm{B}]_{S W}$ increases proportionally to salinity $(\mathrm{S})$. The slope defined by $[\mathrm{B}]$ experiments predicts a $\mathrm{B} / \mathrm{Ca}$ increase of $15 \mu \mathrm{mol} \mathrm{mol}^{-1}$ between 29.9 and $35.4 \mathrm{~S}$ ( 3.84 and $4.55 \mathrm{ppm} \mathrm{B}$, respectively), which agrees with the actual salinity experimental data within measurement error. Thus although the $\mathrm{B} / \mathrm{Ca}$ response to $\mathrm{S}$ is somewhat scattered, it might be explained by higher $[\mathrm{B}]_{s w}$. Overall, the results of our experiments indicate that the concentration of $\mathrm{B}$ in solution has a strong and linear influence on foraminiferal $\mathrm{B} / \mathrm{Ca}$, which needs to be accounted for in both modern and paleo records. If this effect is removed, it decreases the magnitude of glacial-interglacial $\mathrm{B} / \mathrm{Ca}$ records by $\sim 2.6 \mu \mathrm{mol}$ $\mathrm{mol}^{-1}$, exacerbating the low-carbonate-system-sensitivity issue discussed below in Section 4.8 .

\subsection{Temperature}

Theoretically, trace element partitioning (described by $\mathrm{K}_{e q}$ ) should vary with temperature (Stumm and Morgan, 1996). However, because the mechanism for B incorporation is not known, and furthermore since the seawater and calcite phases are not in equilibrium, we have to rely on empirical relationships. $\mathrm{B} / \mathrm{Ca}$ values measured on shells grown between 17.7 and $26.5{ }^{\circ} \mathrm{C}$ agree within error (Fig. 1), and the slope is statistically indistinguishable from zero (Student's t-test, 95\% confidence level). Accounting for the slight $\mathrm{pH}$ difference between our lowest and highest temperature experiments ( -0.1 unit) raises the $\mathrm{B} /$
Ca of the $26{ }^{\circ} \mathrm{C}$ sample from 65 to $68 \mu \mathrm{mol} \mathrm{mol}{ }^{-1}$, but does not change the result of our slope significance-test. The lack of a significant influence of temperature on $\mathrm{B} / \mathrm{Ca}$ (as opposed to $\mathrm{K}_{D}$, which can yield artificial relationships), suggests that for paleo-applications, temperature corrections are not necessary for 0 . universa shells. This further suggests that greater local $\mathrm{CO}_{2}$ sequestration by photosynthetic symbionts at higher temperature (as demonstrated by Bemis et al., 2000) does not significantly affect $\mathrm{B} / \mathrm{Ca}$, at least across the temperature range covered by our experiments.

The impact of temperature on shell chemistry appears to vary by species: B/Ca increases with temperature in G. inflata (Yu et al., 2007), but no effect was observed on the high-latitude species $N$. pachyderma (sinistral) (Hendry et al., 2009). We recommend that until the mechanism(s) of temperature influence on $\mathrm{B} / \mathrm{Ca}$ are better understood, empirical, species-specific temperature influences should be applied to paleo-reconstructions.

\subsection{Proxy implications}

To gain insight into past ocean conditions from fossil calcite records, we must first consider how and where the calcite formed. 0 . universa grows several thin, trochospiral chambers as a juvenile, then secretes a large spherical chamber as an adult, and finally adds a layer of calcite immediately prior to gamete release ("gametogenic calcite") (Spero, 1988). The juvenile portion of its shell only comprises $5-10 \%$ of the total weight (Spero and Parker, 1985), and is generally too fragile to be preserved in marine sediment. This means that geochemical signatures within fossil 0 . universa shells are less likely to have been influenced by ontogenetic (growth) effects than species in which the early-growth or juvenile calcite is preserved. The adult, spherical chamber initially calcifies upon an organic template, and thickens over the course of $\sim 1$ week (Spero, 1988). While most adult calcification is confined to the photic zone to accommodate the light requirements of its symbionts (Bé et al., 1982), some gametogenic calcite ( $4-20 \%$ of total shell mass) may form at greater depths as individuals sink to the thermocline to reproduce (see Hamilton et al., 2008 for a full discussion). All specimens for the present study were collected within $\sim 5 \mathrm{~m}$ of the ocean surface, confirming the presence of this species (both juveniles and adults) in the upper water column. It has been suggested that a few symbiotic foraminifers may even calcify below the thermocline (Lohmann, 1995), but this would put these individuals at a severe disadvantage for survival, calcification and reproduction (Bé, 1972; Hamilton et al., 2008) and such extreme deep-dwellers are rare (Fairbanks et al., 1982). Collectively, these observations suggest that fossil 0 . universa calcite is likely to be dominantly composed of adult-sphere calcite which grew mostly in the photic zone.

If surface ocean $\mathrm{pH}$ and $\mathrm{CO}_{3}^{2-}$ were $\sim 0.15 \mathrm{pH}$ units and $\sim 80 \mu \mathrm{mol}$ $\mathrm{mol}^{-1}$ higher during glacial periods than interglacial periods (Barker and Elderfield, 2002; Hönisch and Hemming, 2005; Sanyal et al., 1995), then based on our calibrations we would expect glacial 0 . universa $\mathrm{B} / \mathrm{Ca}$ to be higher by approximately 5 to $6 \mu \mathrm{mol} \mathrm{mol}{ }^{-1}$. Although it is not yet clear whether one or both (or neither) of these two parameters are truly controlling $\mathrm{B}$ incorporation, the response predicted to the carbonate system is greater than the predicted $\mathrm{B} / \mathrm{Ca}$ increase of $2.6 \mu \mathrm{mol} \mathrm{mol}{ }^{-1}$ in response to a glacial salinity increase of $\sim 1 \%$, suggesting that on glacial-interglacial timescales the carbonate system probably has a stronger influence than salinity on $\mathrm{B} / \mathrm{Ca}$.

Given the typical analytical uncertainty of $2-5 \%$ for B/Ca measurements (Foster, 2008; Yu et al., 2007), and requiring a B/Ca separation of $>4-10 \%$ to determine a significant $(>2 \sigma)$ difference between measured values, then at or near modern ocean conditions ([B/ Ca $]_{\text {universa }} \sim 62 \mu \mathrm{mol} \mathrm{mol}^{-1}$ ) the smallest $\mathrm{pH}$ change resolvable with $\mathrm{B} /$ $\mathrm{Ca}$ in 0 . universa is $\sim 0.1-0.2 \mathrm{pH}$ units. This is as large or larger than the $\mathrm{pH}$ difference between the Holocene and Last Glacial Maximum estimated from boron isotopes (Foster, 2008; Hönisch and Hemming, 2005; Sanyal et al., 1995). Published paleoreconstructions using the foraminifer 
species G. inflata, G. sacculifer and G. ruber have found maximum differences between glacial and interglacial $\mathrm{B} / \mathrm{Ca}$ to be between $\sim 10$ and $25 \mu \mathrm{mol} \mathrm{mol}{ }^{-1}$ (Foster, 2008; Tripati et al., 2009; Yu et al., 2007). This comparison suggests that the B/Ca sensitivity of $G$. inflata, G. sacculifer, and G. ruber may be higher than that of 0 . universa, but the species' relative sensitivities need to be further tested, and we cannot yet rule out enhancement or dampening of the observed glacial-interglacial $\mathrm{B} / \mathrm{Ca}$ ranges by competing factors.

The observed influence of $[\mathrm{B}]_{S W}$ on $\mathrm{B} / \mathrm{Ca}$ in our culture experiments also suggests that paleo-reconstructions using $\mathrm{B} / \mathrm{Ca}$ may need to account for secular changes in the average boron concentration in the ocean. If we apply the relationship observed in culture to the variableriver-input $[\mathrm{B}]_{S W}$ curve of Lemarchand et al. (2000), assuming constant $\mathrm{pH}$ of 8 (total scale), we find that the $\mathrm{B} / \mathrm{Ca}$ adjustments are $<1 \mu \mathrm{mol} \mathrm{mol}{ }^{-1}$ back to 1.2 million years ago (Ma), increasing to $8 \mu \mathrm{mol} \mathrm{mol}^{-1}$ at $15 \mathrm{Ma}$. This suggests that $[\mathrm{B}]_{S W}$ changes are not of great concern until the mid-Miocene. Considering the wide range of $\mathrm{B} /$ Ca observed in different contemporaneous species and the possibility of different responses to $[\mathrm{B}]_{S W}$, this recommendation does not necessarily apply to all planktic foraminifera.

\section{Conclusions}

1. The carbonate system in seawater exerts a measurable control on $\mathrm{B} / \mathrm{Ca}$ of cultured $\mathrm{O}$. universa calcite. Results are broadly consistent with the proxy's existing theoretical framework; however, distinguishing between $\mathrm{pH}, \mathrm{CO}_{3}^{2-}$, or $\mathrm{B}(\mathrm{OH})_{4}^{-} / \mathrm{HCO}_{3}^{-}$control requires further study.

2. Foraminiferal $\mathrm{B} / \mathrm{Ca}$ increases with seawater $\mathrm{B}$ concentration and salinity.

3. Temperature does not significantly influence $\mathrm{B} / \mathrm{Ca}$ in 0 . universa across a range of $17.7-26.5^{\circ} \mathrm{C}$.

4. Laser-ablation profiles through cultured specimens reveal heterogeneous $\mathrm{B} / \mathrm{Ca}$ distributions. $\mathrm{B} / \mathrm{Ca}$ tends to increase from the inner to the outer shell surface, and an anti-correlation with $\mathrm{Mg} / \mathrm{Ca}$ is observed in some individuals.

5. Existing coretop and downcore $\mathrm{B} / \mathrm{Ca}$ data present some puzzling discrepancies, including both positive (Yu et al., 2007) and negative (Foster, 2008) $\mathrm{K}_{D}$-temperature relationships for $G$. ruber, as well as variable $\mathrm{CO}_{3}^{2-}$ influences on $\mathrm{K}_{D}$. Correction for additional controls such as salinity revealed by culturing may remove or reduce these differences and help establish a firmer and more consistent basis for the B/Ca proxy. Though foraminifer shells from coretops grew under natural conditions, their seawater parameters are difficult to constrain. In contrast, culture conditions cannot exactly mimic the foraminifers natural environment, but their growth conditions are very well-known. Combination of these methods can thus support and enhance the use of $\mathrm{B} / \mathrm{Ca}$ as a carbonate system proxy.

\section{Acknowledgments}

We are grateful to all the staff at the USC Wrigley Institute for their support during our field work on Catalina Island. These experiments would not have been possible without the help of Steve Doo, Kelly James, and Lael Vetter, who were dedicated members of our scubadiving and laboratory team. We also thank Ann Russell and Emily Allen for their assistance during the field season, and Jason Day for analysis of seawater at Cambridge University. The manuscript benefitted from the remarks of three anonymous reviewers. This research was funded by NSF grants OCE 07-51764 (BH) and 05-50703 (HJS), ARC grant DP0880010 (SME), and ERC grant 2010-Adg-267931 (HE). This is LDEO contribution No. 7485.

\section{References}

Barker, S., Elderfield, H., 2002. Foraminiferal calcification response to glacialinterglacial changes in atmospheric $\mathrm{CO}_{2}$. Science 297 (5582), 833-836.

Bé, A.W.H., 1972. Zoogeographic Provinces of Holocene planktonic foraminiferida. Am. Assoc. Pet. Geol. Bull. 56 (3), 603.

Bé, A.W.H., Anderson, O.R., 1976. Gametogenesis in planktonic foraminifera. Science 192 (4242), 890-892.

Bé, A.W.H., Spero, H.J., Anderson, O.R., 1982. Effects of symbiont elimination and reinfection on the life processes of the planktonic foraminifer Globigerinoides sacculifer. Mar. Biol. 70 (1), 73-86.

Bemis, B.E., Spero, H.J., Lea, D.W., Bijma, J., 2000. Temperature influence on the carbon isotopic composition of Globigerina bulloides and Orbulina universa (planktonic foraminifera). Mar. Micropaleontol. 38 (3-4), 213-228.

Bentov, S., Brownlee, C., Erez, J., 2009. The role of seawater endocytosis in the biomineralization process in calcareous foraminifera. P. N. A. S. 106 (51), 21500-21504.

Bijma, J., Spero, H., Lea, D., 1999. Use of proxies in Paleoceanography: examples from the South Atlantic. Reassessing Foraminiferal Stable Isotope Geochemistry. Springer-Verlag, pp. 489-512. Ch.

de Nooijer, L.J., Toyofuku, T., Oguri, K., Nomaki, H., Kitazato, H., 2008. Intracellular pH distribution in foraminifera determined by the fluorescent probe HPTS. Limnol. Oceanogr. - Methods 6, 610-618.

Dickson, A.G., 1990. Thermodynamics of the dissociation of boric acid in potassium chloride solutions from 273.15-K to 318.15-K. J. Chem. Eng. Data 35 (3), 253-257.

Dickson, A.G., Sabine, C.L., Christian, J.R. (Eds.), 2007. Guide to Best Practices for Ocean $\mathrm{CO}_{2}$ Measurements, Vol. 3. PICES Special Publication.

Eggins, S., De Deckker, P., Marshall, J., 2002. Laser ablation-ICP-MS compositional profiling of chamber walls in planktonic foraminifera: implications for $\mathrm{Mg} / \mathrm{Ca}$ thermometry. Geochim. Cosmochim. Acta 66 (15A), A207.

Eggins, S., De Deckker, P., Marshall, J., 2003. Mg/Ca variation in planktonic foraminifera tests: implications for reconstructing palaeo-seawater temperature and habitat migration. Earth Planet. Sci. Lett. 212 (3-4), 291-306.

Eggins, S.M., Sadekov, A., De Deckker, P., 2004. Modulation and daily banding of $\mathrm{Mg} / \mathrm{Ca}$ in Orbulina universa tests by symbiont photosynthesis and respiration: a complication for seawater thermometry? Earth Planet. Sci. Lett. 225 (3-4), 411-419.

Elderfield, H., Bertram, C.J., Erez, J., 1996. Biomineralization model for the incorporation of trace elements into foraminiferal calcium carbonate. Earth Planet. Sci. Lett. 142 (3-4), 409-423.

Fairbanks, R.G., Sverdlove, M., Free, R., Wiebe, P.H., Bé, A.W.H., 1982. Vertical distribution and isotopic fractionation of living planktonic foraminifera from the Panama Basin. Nature 298 (5877), 841-844.

Foster, G.L., 2008. Seawater $\mathrm{pH}, \mathrm{pCO}_{2}$ and $\left[\mathrm{CO}^{2-}{ }_{3}\right]$ variations in the Caribbean Sea over the last $130 \mathrm{kyr}$ : a boron isotope and B/Ca study of planktic forminifera. Earth Planet. Sci. Lett. 271 (1-4), 254-266.

Foster, G.L., Pogge von Strandmann, P.A.E., Rae, J.W.B., 2010. Boron and magnesium isotopic composition of seawater. Geochem. Geophys. Geosyst. 11, Q08015

Hamilton, C.P., Spero, H.J., Bijma, J., Lea, D.W., 2008. Geochemical investigation of gametogenic calcite addition in the planktonic foraminifera Orbulina universa. Mar. Micropaleontol. 68 (3-4), 256-267.

Hemming, N.G., Hanson, G.N., 1992. Boron isotopic composition and concentration in modern marine carbonates. Geochim. Cosmochim. Acta 56 (1), 537-543.

Hemming, N.G., Reeder, R.J., Hanson, G.N., 1995. Mineral-fluid partitioning and isotopic fractionation of boron in synthetic calcium carbonate. Geochim. Cosmochim. Acta 59 (2), 371-379.

Hendry, K.R., Rickaby, R.E.M., Meredith, M.P., Elderfield, H., 2009. Controls on stable isotope and trace metal uptake in Neogloboquadrina pachyderma (sinistral) from an Antarctic sea-ice environment. Earth Planet. Sci. Lett. 278, 67-77.

Hobbs, M.Y., Reardon, E.J., 1999. Effect of $\mathrm{pH}$ on boron coprecipitation by calcite: Further evidence for nonequilibrium partitioning of trace elements. Geochim. Cosmochim. Acta 63 (7-8), 1013-1021.

Hönisch, B., Hemming, N.G., 2004. Ground-truthing the boron isotope-paleo-pH proxy in planktonic foraminifera shells: partial dissolution and shell size effects. Paleoceanography 19 (4), PA4010.

Hönisch, B., Hemming, N.G., 2005. Surface ocean $\mathrm{pH}$ response to variations in $\mathrm{pCO}_{2}$ through two full glacial cycles. Earth Planet. Sci. Lett. 236 (1-2), 305-314.

Hönisch, B., Bijma, J., Russell, A.D., Spero, H.J., Palmer, M.R., Zeebe, R.E., Eisenhauer, A., 2003. The influence of symbiont photosynthesis on the boron isotopic composition of foraminifera shells. Mar. Micropaleontol. 49 (1-2), 87-96.

Hönisch, B., Hemming, N.G., Loose, B., 2007. Comment on "A critical evaluation of the boron isotope-pH proxy: the accuracy of ancient ocean pH estimates" by M. Pagani, D. Lemarchand, A. Spivack and J. Gaillardet. Geochim. Cosmochim. Acta 71 (6), 1636-1641.

Hönisch, B., Hemming, N.G., Archer, D., Siddall, M., McManus, J.F., 2009. Atmospheric carbon dioxide concentration across the Mid-Pleistocene transition. Science 324 (5934), 1551-1554.

Jørgensen, B.B., Erez, J., Revsbech, N.P., Cohen, Y., 1985. Symbiotic photosynthesis in a planktonic foraminiferan, Globigerinoides sacculifer (Brady), studied with microelectrodes. Limnol. Oceanogr. 30 (6), 1253-1267.

Katz, M.E., Cramer, B.S., Franzese, A., Hönisch, B., Miller, K.G., Rosenthal, Y., Wright, J.D. 2010. Traditional and emerging geochemical proxies in foraminifera. J. Foraminifer. Res. 40 (2), 165-192.

Klochko, K., Kaufman, A.J., Yao, W., Byrne, R.H., Tossell, J.A., 2006. Experimental measurement of boron isotope fractionation in seawater. Earth Planet. Sci. Lett. 248 (1-2), 276-285. 
Klochko, K., Cody, G.D., Tossell, J.A., Dera, P., Kaufman, A.J., 2009. Re-evaluating boron speciation in biogenic calcite and aragonite using ${ }^{11} \mathrm{~B}$ MAS NMR. Geochim. Cosmochim. Acta 73 (7), 1890-1900.

Krief, S., Hendy, E.J., Fine, M., Yam, R., Meibom, A., Foster, G.L., Shemesh, A., 2010. Physiological and isotopic responses of scleractinian corals to ocean acidification. Geochim. Cosmochim. Acta 74 (17), 4988-5001.

Langer, M.R., 1992. Biosynthesis of glycosaminoglycans in Foraminifera - a review. Mar. Micropaleontol. 19 (3), 245-255.

Lea, D.W., 2003. Elemental and Isotopic Proxies of Past Ocean Temperatures. Vol. 6 of Treatise on Geochemistry. Elsevier.

Lee, J.J., Anderson, O.R., 1991. Biology of Foraminifera. Academic Press.

Lee, K., Kim, T.W., Byrne, R.H., Millero, F.J., Feely, R.A., Liu, Y.M., 2010. The universal ratio of boron to chlorinity for the North Pacific and North Atlantic oceans. Geochim. Cosmochim. Acta 74 (6), 1801-1811.

Lemarchand, D., Gaillardet, J., Lewin, E., Allègre, C.J., 2000. The influence of rivers on marine boron isotopes and implications for reconstructing past ocean $\mathrm{pH}$. Nature 408 (6815), 951-954.

Lohmann, G.P., 1995. A model for variation in the chemistry of planktonic foraminifera due to secondary calcification and selective dissolution. Paleoceanography 10 (3), 445-457.

Lueker, T.J., Dickson, A.G., Keeling, C.D., 2000. Ocean $\mathrm{pCO}_{2}$ calculated from dissolved inorganic carbon, alkalinity, and equations for $\mathrm{K}-1$ and $\mathrm{K}-2$ : validation based on laboratory measurements of $\mathrm{CO}_{2}$ in gas and seawater at equilibrium. Mar. Chem. 70 (1-3), 105-119.

Mackin, J.E., 1986. The free-solution diffusion coefficient of boron: Influence of dissolved organic matter. Mar. Chem. 20, 131-140.

Morse, J.W., 1986. The surface chemistry of calcium carbonate minerals in natural waters - an overview. Mar. Chem. 20 (1), 91-112.

Morse, J.W. Bender, M.L., 1990. Partition coefficients in calcite - examination of factors influencing the validity of experimental results and their application to natural systems. Chem. Geol. 82 (3-4), 265-277.

Ni, Y.Y., Foster, G.L., Bailey, T., Elliott, T., Schmidt, D.N., Pearson, P., Haley, B., Coath, C. 2007. A core top assessment of proxies for the ocean carbonate system in surfacedwelling foraminifers. Paleoceanography 22 (3), PA3212.

Paillard, D.L.L., Yiou, P., 1996. Macintosh program performs time-series analysis. Eos Trans. AGU 77, 379

Rae, J.W.B., Foster, G.L., Schmidt, D.N., Elliott, T., 2011. Boron isotopes and B/Ca in benthic foraminifera: proxies for the deep ocean carbonate system. Earth Planet. Sci. Lett. 302, 403-413.

Riley, J.P., Tongudai, M., 1967. The major cation/chlorinity ratios in seawater. Chem. Geol. 2, 263-269.

Rink, S., Kuhl, M., Bijma, J., Spero, H.J., 1998. Microsensor studies of photosynthesis and respiration in the symbiotic foraminifer Orbulina universa. Mar. Biol. 131 (4), 583-595.

Russell, A.D., Hönisch, B., Spero, H.J., Lea, D.W., 2004. Effects of seawater carbonate ion concentration and temperature on shell $\mathrm{U}, \mathrm{Mg}$, and $\mathrm{Sr}$ in cultured planktonic foraminifera. Geochim. Cosmochim. Acta 68 (21), 4347-4361.

Sanyal, A., Hemming, N.G., Hanson, G.N., Broecker, W.S., 1995. Evidence for a higher pH in the glacial ocean from boron isotopes in foraminifera. Nature 373 (6511) 234-236.

Sanyal, A., Hemming, N.G., Broecker, W.S., Lea, D.W., Spero, H.J., Hanson, G.N., 1996. Oceanic $\mathrm{pH}$ control on the boron isotopic composition of foraminifera: evidence from culture experiments. Paleoceanography 11 (5), 513-517.
Sanyal, A., Nugent, M., Reeder, R.J., Bijma, J., 2000. Seawater pH control on the boron isotopic composition of calcite: evidence from inorganic calcite precipitation experiments. Geochim. Cosmochim. Acta 64 (9), 1551-1555.

Sanyal, A., Bijma, J., Spero, H.J., Lea, D.W., 2001. Empirical relationship between pH and the boron isotopic composition of Globigerinoides sacculifer: implications for the boron isotope paleo-pH proxy. Paleoceanography 16 (5), 515-519.

Sen, S., Stebbins, J.F., Hemming, N.G., Ghosh, B., 1994. Coordination environments of Bimpurities in calcite and aragonite polymorphs: a ${ }^{11} \mathrm{~B}$ MAS NMR-study. Am. Mineral. 79 (9-10), 819-825.

Spero, H.J., 1988. Ultrastructural examination of chamber morphogenesis and biomineralization in the planktonic foraminifer Orbulina universa. Mar. Biol. 99 (1), 9-20.

Spero, H.J., Parker, S.L., 1985. Photosynthesis in the symbiotic planktonic foraminifer Orbulina universa and its potential contribution to oceanic primary productivity. J. Foraminifer. Res. 15 (4), 273-281.

Spero, H.J., Bijma, J., Lea, D.W., Bemis, B.E., 1997. Effect of seawater carbonate concentration on foraminiferal carbon and oxygen isotopes. Nature 390 (6659), 497-500.

Spero, H.J., Mielke, K.M., Kalve, E.M., Lea, D.W., Pak, D.K., 2003. Multispecies approach to reconstructing eastern equatorial Pacific thermocline hydrography during the past 360 kyr. Paleoceanography 18 (1), 1022.

Stumm, W., Morgan, J.J., 1996. Aquatic Chemistry: Chemical Equilibria and Rates in Natural Waters. John Wiley and Sons, Inc.

Tossell, J.A., 2006. Boric acid adsorption on humic acids: ab initio calculation of structures, stabilities, ${ }^{11} \mathrm{~B}$ NMR and ${ }^{11} \mathrm{~B},{ }^{10} \mathrm{~B}$ isotopic fractionations of surface complexes. Geochim. Cosmochim. Acta 70 (20), 5089-5103.

Tripati, A.K., Roberts, C.D., Eagle, R.A., 2009. Coupling of $\mathrm{CO}_{2}$ and ice sheet stability over major climate transitions of the last 20 million years. Science 326 (5958), 1394-1397.

van Cappellen, P., Charlet, L., Stumm, W., Wersin, P. 1993. A surface complexation model of the carbonate mineral-aqueous solution interface. Geochim. Cosmochim. Acta 57 (15), 3505-3518.

Wolf-Gladrow, D.A., Bijma, J., Zeebe, R.E., 1999. Model simulation of the carbonate chemistry in the microenvironment of symbiont bearing foraminifera. Mar. Chem. 64 (3), 181-198

Yu, J., 2006. Boron concentration in foraminifera as a proxy for glacial-interglacial change in the oceanic carbonate system. Ph.D. thesis, 155 pp., University of Cambridge, U. K.

Yu, J.M., Elderfield, H., Hönisch, B., 2007. B/Ca in planktonic foraminifera as a proxy for surface seawater pH. Paleoceanography 22 (2), PA2202.

Yu, J.M., Foster, G.L., Elderfield, H., Broecker, W.S., Clark, E., 2010. An evaluation of benthic foraminiferal $\mathrm{B} / \mathrm{Ca}$ and delta $\mathrm{B}-11$ for deep ocean carbonate ion and $\mathrm{pH}$ reconstructions. Earth Planet. Sci. Lett. 293 (1-2), 114-120.

Zeebe, R.E. 1999. An explanation of the effect of seawater carbonate concentration on foraminiferal oxygen isotopes. Geochim. Cosmochim. Acta 63 (13-14), 2001-2007.

Zeebe, R.E., Sanyal, A., 2002. Comparison of two potential strategies of planktonic foraminifera for house building: $\mathrm{Mg}^{2+}$ or $\mathrm{H}^{+}$removal? Geochim. Cosmochim. Acta 66 (7), 1159-1169.

Zeebe, R.E., Wolf-Gladrow, D.A., 2004. A matlab program for calculating the carbonate system (csys3.m). URL: http://www.soest.hawaii.edu/oceanography/faculty/ zeebe.

Zuddas, P., Pachana, K., Faivre, D., 2003. The influence of dissolved humic acids on the kinetics of calcite precipitation from seawater solutions. Chem. Geol. 201 (1-2), 91-101. 